\title{
Two-stage regional rare-element pegmatite formation at Tysfjord, Norway: implications for the timing of late Svecofennian and late Caledonian high-temperature events
}

\author{
Axel Müller ${ }^{1,2}$ (1) $\cdot$ Rolf L. Romer ${ }^{3} \cdot$ Lars Eivind Augland $^{4} \cdot$ Haoyang Zhou ${ }^{1} \cdot$ Nanna Rosing-Schow $^{1} \cdot$ John Spratt $^{2}$. \\ Tomas Husdal $^{1}$
}

Received: 20 September 2021 / Accepted: 22 January 2022 / Published online: 16 February 2022

(c) The Author(s) 2022

\begin{abstract}
Pegmatite fields within granite plutons are commonly considered to have formed from residual melts of their host. This is not always true as demonstrated by the Tysfjord granite gneiss and its two groups of pegmatites. The Tysfjord granite gneiss, exposed in a tectonic window of the Caledonides of northern Norway, is part of the transscandinavian igneous belt (TIB) that includes several phases of granitic magmatism. In the northern Hamarøy area (Drag-Finnøy), where most rare-element pegmatites occur, Paleoproterozoic and metamorphosed Group 1 allanite-(Ce)-fluorite metapegmatites have similar bulk rock chemical composition as the TIB granite gneiss rocks, indicating that these pegmatites are residual melts. Group 1 metapegmatites, which are up to $400 \mathrm{~m}$ in size, are among the largest known intra-plutonic pegmatites with $\mathrm{Nb}-\mathrm{Y}-\mathrm{F}$ (NYF) signature. The formation of these unusually large granite-hosted NYF pegmatites may have been facilitated by the overall high $\mathrm{F}$ content of TIB granite gneisses. Undeformed Group 2 amazonite-tourmaline pegmatites yield columbite and zircon U-Pb ages in the range 400-379 Ma. These pegmatites are interpreted to be anatectic melts that formed from the partial melting of Tysfjord granite gneiss. Group 2 pegmatites, including those from Træna Island and the Sjona tectonic window (400 and $414 \mathrm{Ma}$ ), formed during late Caledonian ductile shearing and incipient unroofing of the central Scandinavian Caledonides and record progressively younger ages of this event from SW to NE.
\end{abstract}

Keywords U-Pb dating $\cdot$ Pegmatite $\cdot$ Anatexis $\cdot$ Svecofennian $\cdot$ Caledonian $\cdot$ Tysfjord

\section{Introduction}

Granites in orogenic and anorogenic settings are often spatially associated with pegmatites that may be enriched in incompatible elements. Based on this spatial relation, pegmatites are commonly interpreted to have formed from

Axel Müller

a.b.muller@nhm.uio.no

1 Natural History Museum, University of Oslo, Blindern, P.O. Box 1172, 0318 Oslo, Norway

2 Natural History Museum, Cromwell Road, London SW7 5BD, England

3 GFZ German Research Centre for Geosciences, Telegrafenberg, 14473 Potsdam, Germany

4 Centre for Earth Evolution and Dynamics (CEED), University of Oslo, Blindern, P.O. Box 1028, 0315 Oslo, Norway residual melts derived from crystallizing granitic plutons (e.g. Černý 1991; Černý and Ercit 2005; London 2008). Such a genetic relation certainly applies for numerous pegmatite fields, in particular for pegmatite fields that are hosted within the parental pluton (e.g. Janeczek 2007; Thomas and Davidson 2016; Falster et al. 2018; Roda-Robles et al. 2018) and that show the same chemical character and age as the associated granite (e.g. Garate-Olave et al. 2017). There is, however, an increasing number of case studies yielding contrasting ages for pegmatites and spatially associated granites and, thus, showing that there are rare-element pegmatites without an associated source granite (e.g. Romer and Smeds 1994, 1996; Fuchsloch et al. 2018; Konzett et al. 2018; Müller et al. 2015, 2017; Schuster et al. 2017; Barros and Menuge 2016; Ilickovic et al. 2017; Knoll et al. 2018; Simmons et al. 1996, 2016; Webber et al. 2019; Fei et al. 2020). These studies imply that not all chemically evolved pegmatites form from residual melts of chemically evolved plutons. The absence of an exposed coeval granite, however, 
does not exclude the possibility that there is a hidden granite intrusion at depth.

The Paleoproterozoic granites of the Tysfjord-Hamarøy area in north Norway host a suite of pegmatites that traditionally have been interpreted as a typical example of pegmatites being fractionated derivatives of their granitic host. These Paleoproterozoic rocks were metamorphosed and deformed under amphibolite-facies conditions during the Caledonian orogeny about 430 Ma ago (Björklund 1989; Northrup 1997). Based on field observations, there are two generations of pegmatites emplaced in the Paleoproterozoic Tysfjord granite gneiss (Husdal 2008). Although both pegmatite generations show similar mineralogy, the older generation of pegmatites is strongly deformed (sheared and recrystallized and referred to as metapegmatites in the following), whereas the younger generation does not show particular signs of deformation and metamorphic overprint. There are no age data available for these pegmatites, except for a recent study from Hetherington et al. (2021) reporting ages of 400-410 Ma for one of the strongly deformed metapegmatites. A systematically geochronological study is required to explore the possibility that there might be two pegmatite-forming events.

Dating pegmatitic minerals has been challenging as most geochronometers in pegmatites are extremely rich in $U$ and thus have become metamict. Columbite has been proven to be a robust geochronometer as metamict domains preferentially dissolve and thus can be removed. In this study, we present columbite and zircon $\mathrm{U}-\mathrm{Pb}$ age data for two petrographically and texturally distinct groups of pegmatites within the Tysfjord granite gneiss. We demonstrate that the two groups of pegmatites have different ages, i.e., Paleoproterozoic and Paleozoic, respectively, and are related to late Svecofennian and late Caledonian orogenic processes. We discuss the origin of the two pegmatite generations and their genetic relations with the granitic rocks of the Tysfjord area and the processes that led to the formation of two generations of mineralogically similar rare element pegmatite in the same region.

\section{Geology of Tysfjord-Hamarøy area}

\section{The Transscandinavian Igneous Belt as part of the Baltic Shield}

The Baltic Shield includes an Archean Domain in the northeast, an early Paleoproterozoic Domain, i.e., the Svecofennian Domain, in the central part, and a Neoproterozoic segment, i.e., the Sveconorwegian Domain, in the southwest. Between the Svecofennian and the Sveconorwegian domains lies a major magmatic belt, the Transscandinavian Igneous Belt (TIB, inset in Fig. 1). At the western margin of the Baltic Shield, all four domains were overprinted by the Caledonian orogen. The Archean domain is dominated by greenstones and trondhjemite-tonalite-granite intrusions. The Svecofennian Domain includes several c. 1.9 Ga magmatic arcs that were accreted to the Archean craton before $1.82 \mathrm{Ga}$. The boundary between the Archean craton and the various magmatic arcs locally developed into major strikeslip shear zones (inset in Fig. 1). To the south and west, the Svecofennian Domain is succeeded by the $1.85-1.65 \mathrm{Ga}$ TIB (e.g. Gorbatschev 1985; Högdahl et al. 2004). The TIB represent the remains of a former Andean-type magmatic arc, which comprises a giant elongated array of batholiths extending for c. $1400 \mathrm{~km}$ from southeasternmost Sweden to Troms in north-western Norway. The magmatic rocks of the TIB belt are not coeval along the belt, which is segmented by the NW-SE striking Paleoproterozoic shear zones extending into the Svecofennian Domain. Within the Caledonian orogen, TIB rocks are exposed in several basement windows. The position of the $\mathrm{N}-\mathrm{S}$ aligned basement windows is controlled by the former continental margin and the repeatedly reactivated NW-SE striking shear zones (Romer and Bax 1992).

The Tysfjord granite gneiss, which hosts the studied pegmatites, belongs regionally to the TIB. The TIB granites are subalkaline to alkaline, meta- to peraluminous and comprise monzonitic, syenitic and peralkaline granitic plutons, locally with volcanic complexes (e.g., Högdahl et al. 2004). Mafic rocks are abundant in many areas, and mingling/mixing structures are common. Isotopic data show that the TIB has dominantly formed by reworking juvenile $(2.1-1.87 \mathrm{Ga})$ Svecofennian crust, supplemented by mantle material in a continental-arc setting. There are at least two groups of TIB rocks that differ in age and chemical composition. The oldest TIB rocks (TIB-1; 1.85-1.76 Ga) are coeval with post-kinematic granites within the Svecofennian Domain and tend to occur in vicinity of the margin to the domain (Högdahl et al. 2004). The youngest TIB rocks (TIB-2; 1.72-1.65 Ga) dominate the central TIB and partially overlap in age with the rapakivi magmatism in south Finland (e.g. Suominen 1991; Vaasjoki et al. 1991).

\section{Tectonic development of the Caledonides}

The Caledonian orogen is the result of the collision of the continents Laurentia and Baltica in the Silurian, which marks the final stage of the closure of the Iapetus Ocean that had started already in the Ordovician (e.g. Gee and Sturt 1985; Kroner et al. 2020). The nappe complexes of the Scandinavian Caledonides have traditionally been divided into four major tectonic units, named Lower Allochthon, Middle Allochthon, Upper Allochthon, and Uppermost Allochthon, of contrasting provenance and tectonic and metamorphic history (Gee and Sturt 1985; Roberts and Gee 1985; Gee et al. 


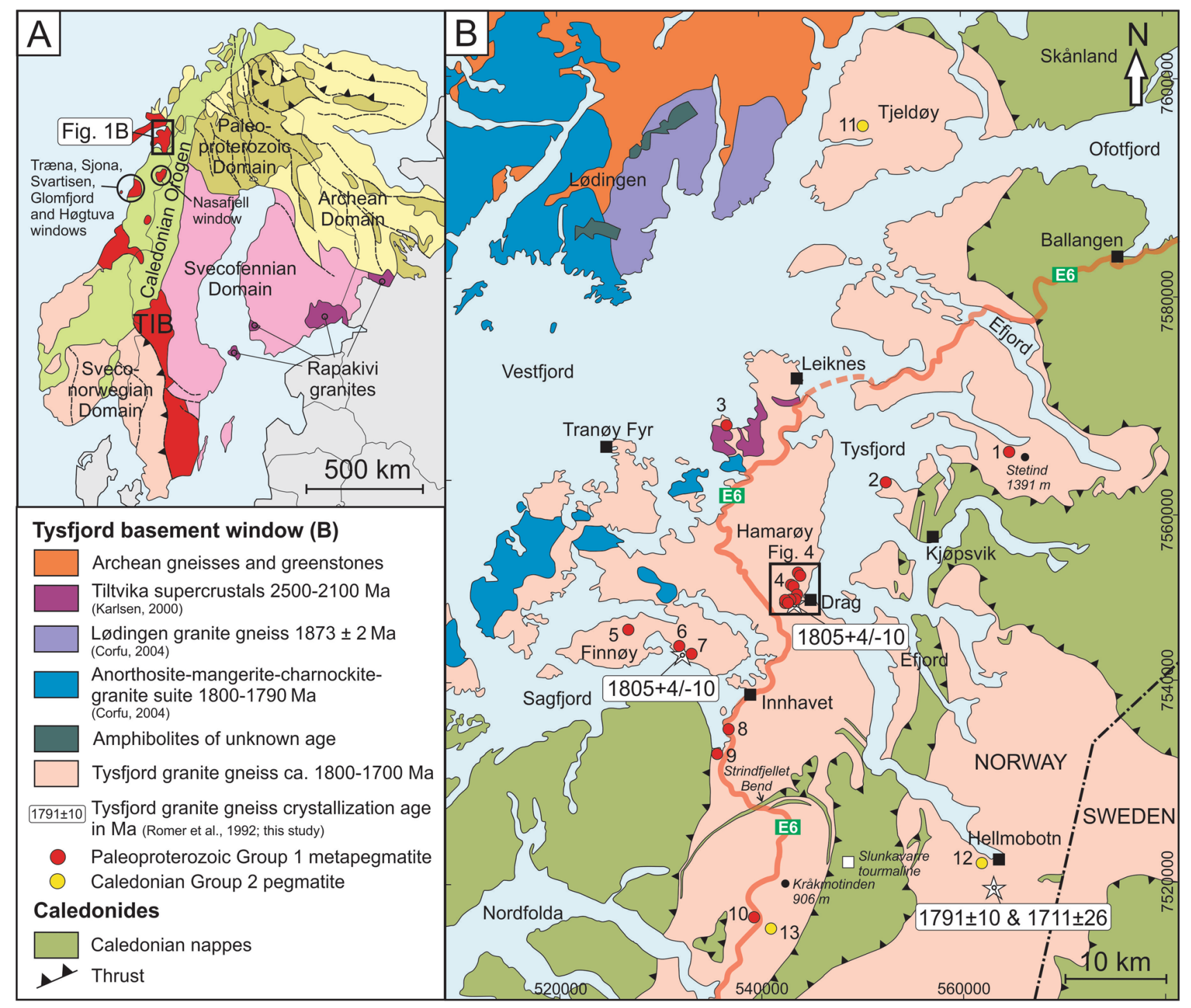

Fig. 1 A Major Archean and Proterozoic orogens and domains building up Fennoscandia with the location of the study area. Simplified from Bergh et al. (2014). TIB, Transscandinavian Igneous Belt; B simplified geological map of the northern Tysfjord basement window with locations of (meta-)pegmatites of the Tysfjord field. Pegmatites:
Group 1: 1, Stetind; 2, Hundholmen; 3, Tiltvika; 4, Drag metapegmatite cluster including Nedre Øyvollen; 5, Håkonhals; 6, Karlsøy; 7, Oteråga; 8, Lagmannsvik; 9, Elveneset; 10, Kråkmo; Group 2: 11, Tjeldøya; 12, Hellmobotn; 13, Tennvatn

thrusting within the basement (Thelander et al. 1980; Greiling et al. 1993; Rice 2001; Rice and Anderson 2016). The northern and southern margins of the eastern basement windows (e.g. Rombak and Nasafjell) correspond to the NW-SE striking faults in the Svecofennian Domain (Romer and Bax 1992). At these margins, numerous N-S striking faults show minor offset of the contact between the basement and its sedimentary cover, providing direct evidence that the basement was reworked during the Caledonian orogeny. In fact, the structure of the Strindfjellet Bend in the central Tysfjord window (Fig. 1B) documents that the Tysfjord granite gneiss was locally thrust over rocks of the Caledonian nappes. formal stacks of basement rocks, which are exposed in two chains along the Caledonian orogeny, document large-scale 
Towards the centre of the basement windows, these numerous small faults combine to larger $\mathrm{N}-\mathrm{S}$ striking steeply dipping faults with major offset, causing the highest culminations of granitic basement in the centre of the windows to be more than $1300 \mathrm{~m}$ higher than the basement-cover contact at the northern and southern margins of the windows (cf. Romer and Bax 1992; Romer et al. 1994). The western basement windows, including the Tysfjord window, experienced a similar reworking during the Caledonian orogeny, although at higher metamorphic grade and with more intense deformation of the granitic rocks. Within these windows, folds, fold-trains, lineations and S-C fabrics preserve a top-ENE transport direction interpreted to record early thrusting and nappe emplacement, probably near the onset of continental collision (Larsen et al. 2002; Osmundsen et al. 2003). The gneissose foliation of the basement rocks is suggested to have evolved during the antiformal stacking and unroofing of the gneissic-granite-cored culminations (Gromet and Andresen 1993; Larsen et al. 2002; Dewey and Strachan 2003; Osmundsen et al. 2003).

The former basement and Caledonian nappes underwent different grades of prograde and retrograde metamorphism ranging from greenschist to high-grade amphibolite facies (c. 430-410 Ma; Northrup 1997; Steltenpohl et al. 2003). Post-orogenic extension (c. 410-380 Ma) was related to the beginning collision between Gondwana and Laurentia in the south (Fossen 2010; Kroner et al. 2020). The widespread, Early-Mid-Devonian top-W to -SW ductile extension resulted in the reactivation of $\mathrm{N}-\mathrm{S}$ to NW-SE striking faults (Eide et al. 2002).

\section{The Tysfjord basement window}

The Tysfjord pegmatites and granite gneiss are exposed in a tectonic window in the Caledonides of northern Norway, the Tysfjord basement window. The Tysfjord granite gneisses occupy about $4000 \mathrm{~km}^{2}$ and cover almost the entire window (Fig. 1). Only in the north and northwest, at Hamarøy, volcanic and sedimentary Svecofennian supracrustal rocks with ages of 2500-2100 Ma and 1910-1880 Ma are preserved (Karlsen 2000). To the north of Vestfjorden, the window continues into the Lofoten-Vesterålen basement complex. The oldest rocks of that complex are remnants of an Archean greenstone belt that have been intruded by anorthositic, mangeritic, charnockitic, and granitic (AMCG) rocks (Griffin et al. 1978) between 1870 and $1790 \mathrm{Ma}$ (e.g. Corfu 2004) and by the Tysfjord granite gneiss, which form the Tjeldøya island (Fig. 1). In the west, south and southeast, the Tysfjord window is framed by overlying Caledonian nappe complexes. The nappes belong to the upper part of the
Upper Allochthon and the Uppermost Allochthon. The Upper Allochthon, to the west and south of the Tysfjord window, forms an up to $5 \mathrm{~km}$ thick nappe stack comprising the Narvik, Ofoten amd Niingen Nappe Complexes (Barker 1986; Steltenpohl and Bartley 1987; Andresen and Steltenpohl 1994; Anderson and Barker 1999). The Uppermost Allochthon in the south consists of the Fauske and Rødingsfjellet Nappe Complexes (e.g. Roberts et al. 2007).

\section{The Tysfjord granite gneiss}

The Tysfjord granite gneiss is a coarse-grained, foliated, pale grey to pale red, partly recrystallized metagranite with biotite, hornblende, quartz, K-feldspar, and oligoclase-albite. Accessory minerals include allanite-(Ce), titanite, zircon, apatite, magnetite, fluorite, polycrase-(Y), and thorianite (Müller 2011). The emplacement of the TIB is related to the last stage of the Svecofennian orogeny (1.92-1.79 Ga; Lahtinen et al. 2008, 2009). The TIB has been interpreted as an Andean-type belt or as a continental belt (Högdahl et al. 2004). The TIB magmatism has been tentatively separated into two different episodes: the little fractionated, TIB-1 group with predominant I-type signature and emplacement ages of 1850 to $1760 \mathrm{Ma}$ and the more fractionated TIB-2 group of A-type affinity with ages between 1720 and 1650 Ma (Skår 2002; Högdahl et al. 2004; Lahtinen et al. 2008). Both groups occur in the Tysfjord window (Romer et al. 1992). Samples from the Hellmobotn $(25 \mathrm{~km} \mathrm{SE}$ of Drag) have a bimodal U-Pb zircon age distribution of $1791 \pm 10 \mathrm{Ma}$ (TIB-1) and $1711 \pm 26 \mathrm{Ma}$ (TIB-2), respectively (Romer et al. 1992) (Fig. 1). The foliation and recrystallization of the granites extends at least $2500 \mathrm{~m}$ down from the overlying (now eroded) Caledonian nappes (Andresen and Tull 1986). The foliation developed under amphibolite-facies conditions during the Caledonian orogeny at c. 432 Ma (Northrup 1997).

\section{The Tysfjord (meta-)pegmatites}

The Tysfjord pegmatites are of the $\mathrm{Nb}-\mathrm{Y}-\mathrm{F}$ (NYF) type (applying the classification of Černý 1991) and occur within the Tysfjord granite gneiss. Major minerals are quartz, K-feldspar, plagioclase and biotite. Main accessory minerals are allanite- $(\mathrm{Ce})$, fergusonite-(Y), columbite- $(\mathrm{Fe})$, thalénite-(Y), gadolinite- $(Y)$, beryl, various sulfides (pyrite, pyrrhotite, arsenopyrite) and Y-rich fluorite with abundant inclusions of various REE-minerals (Husdal 2008).

Pegmatite mining has a more than 100-year long tradition in the Tysfjord-Hamarøy area. Mining of ceramic feldspar started at Hundholmen in 1906 and in numerous pegmatites in the Drag area in 1907, and lasted until the 1970s. Mining took up again in 1996 at Nedre Øyvollen, this time for the 


\begin{tabular}{|c|c|c|}
\hline & Group 1: Metapegmatites & Group 2: Pegmatites \\
\hline Structure & $\begin{array}{l}\text { Tysfjord granite, } \\
\text { gneiss }\end{array}$ & Covity \\
\hline Size & Large, up to 1.5 million $\mathrm{m}^{3}$ & Small, $<1000 \mathrm{~m}^{3}$ \\
\hline Shape & Lenticular to cigar-shaped & Dyke-like \\
\hline $\begin{array}{c}\text { Indicative } \\
\text { main } \\
\text { minerals }\end{array}$ & $\begin{array}{l}\text { Pink and white K-feldspar (amazonite is } \\
\text { very rare), biotite, plagioclase }\end{array}$ & $\begin{array}{l}\text { Amazonite as only K-feldspar, albite } \\
\text { (cleavelandite), poor in mica }\end{array}$ \\
\hline \begin{tabular}{|c|} 
Indicative \\
accessories
\end{tabular} & $\begin{array}{l}\text { Allanite-(Ce), beryl, fluorite, thalénite- } \\
\qquad(Y) \text {, sulfides }\end{array}$ & $\begin{array}{l}\text { Tourmaline, beryl, fluorite, } \\
\text { gadolinite group minerals }\end{array}$ \\
\hline Chemistry & Primitive to moderately evolved NYF & Highly evolved NYF \\
\hline Deformation & Recrystallized and sheared & Undeformed \\
\hline Other & $\begin{array}{l}\text { Pegmatite is massive (no cavities) and } \\
\text { concordant to host rock foliation }\end{array}$ & $\begin{array}{l}\text { Pegmatite has small cavities and is } \\
\text { discordant to host rock foliation }\end{array}$ \\
\hline
\end{tabular}

Fig. 2 Structural and mineralogical features of Group 1 metapegmatites and Group 2 pegmatites of the Tysfjord basement window

production of high purity quartz (quartz with $<50 \mathrm{ppm}$ contaminating elements). The Nedre Øyvollen and Håkonhals pegmatites, and most of the other Tysfjord pegmatites, contain quartz whose exceptionally low concentrations of trace elements made it applicable to specific high-tech products, such as quartz glass crucibles. Compared with quartz from other pegmatites, the Tysfjord pegmatite quartz is one of the purest worldwide (Müller et al. 2013).

Husdal (2008) distinguished two genetic groups of pegmatites within the Tysfjord field based on their degree of deformation and average body size (Fig. 2). Group 1 metapegmatites underwent ductile deformation resulting in large-scale shearing of the pegmatite bodies and partial or complete recrystallization of pegmatite minerals (Fig. 3A and $\mathrm{B})$. Because of the deformation, the primary magmatic zoning of the metapegmatites-border, wall, intermediate and core zones-is preserved only locally. The fine- to medium-grained granitic wall zone shows a distinct foliation, which is parallel to the metapegmatite contacts. The wall zone gradually changes into large, irregularly shaped masses of recrystallized megacrystic K-feldspar and plagioclase embedded in quartz, representing the intermediate zone. In this zone, K-feldspar is much more common than plagioclase. Most Group 1 metapegmatites have a massive quartz core (Fig. 2). In the strongly deformed metapegmatites, such as Håkonhals, large-scale (5-20 m) boudins of the intermediate zone and core are blended. Characteristic accessory minerals are allanite- $(\mathrm{Ce})$, fluorite, thalenite-(Y), beryl and sulphides (pyrrhotite, löllingite, galena, pyrite and chalcopyrite). Most Group 1 metapegmatites, 21 bodies, occur around the village Drag, aligned at a $4 \mathrm{~km}$ long structure (Fig. 4). Additional Group 1 metapegmatites (about 10 bodies) seem to be randomly distributed across the northern Tysfjord basement window.

Group 2 pegmatites occur as preferentially N-Sstriking, dyke-like bodies, which were not affected by deformation (Figs. 2 and 3C). Distinct mineralogical zoning and 'cleavelandite' (platy shape variety of albite) replacement zones are developed. Intense green coloured K-feldspar (amazonite) and abundant black tourmaline are typical for Group 2 pegmatites (Fig. 3D). Typical accessory minerals are schorl, magnetite, beryl, fluorite, gadolinite group minerals, helvine group minerals, columbite-( $\mathrm{Mn})$, columbite- $(\mathrm{Fe})$, various $\mathrm{Pb}-\mathrm{Bi}$ sulfides 


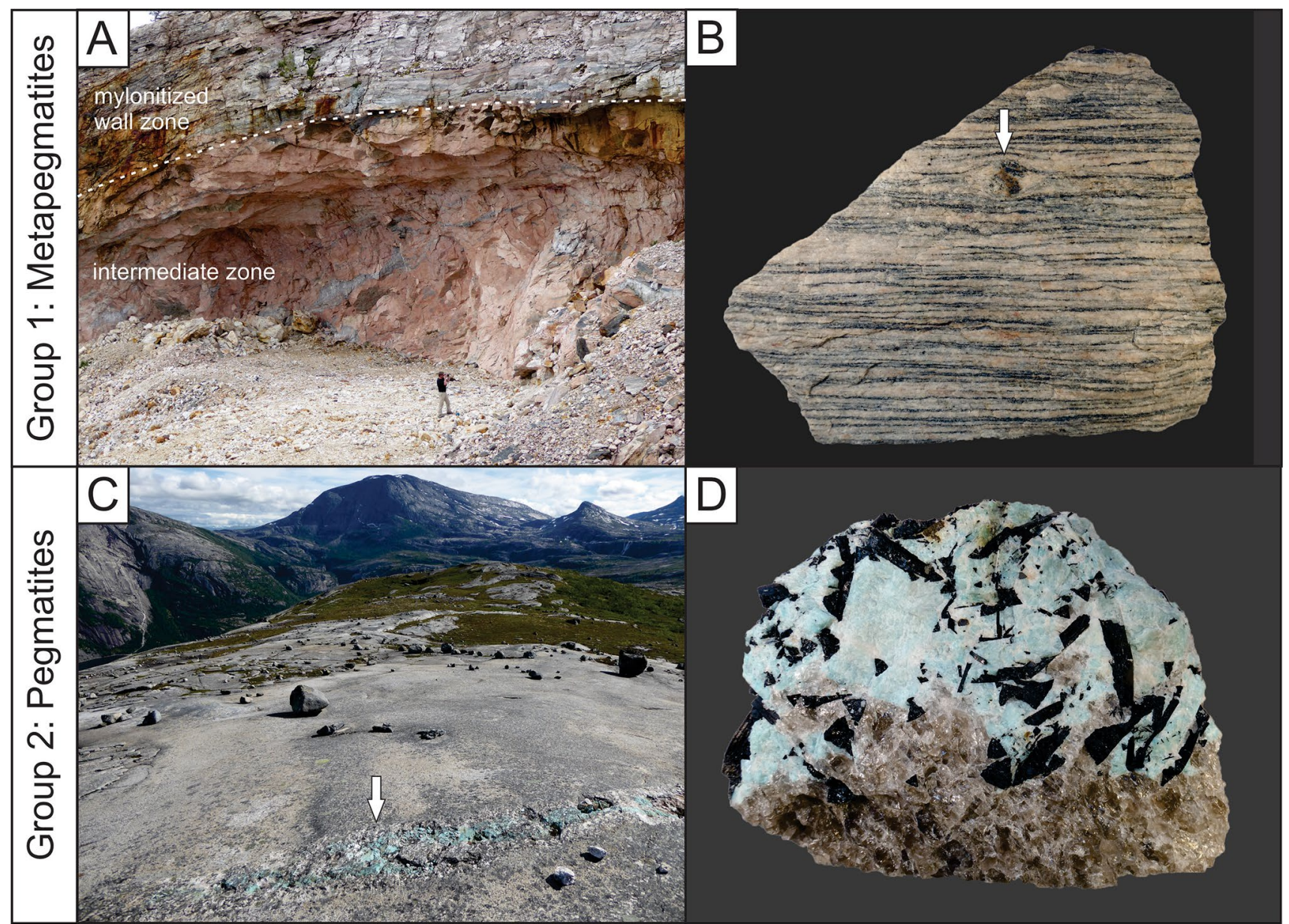

Fig. 3 A North wall of the Håkonhals mine exposing the uppermost part of the Håkonhals Group 1 metapegmatite comprising the up to $8 \mathrm{~m}$ thick mylonitized wall zone and the K-feldspar-dominated intermediate zone. See person for scale. B Handspecimen $(14 \mathrm{~cm}$ in length) of the mylonitized wall zone of the Håkonhals metapegma-

and sulfosalts, zircon, thorite, xenotime-(Y) and metamict $(\mathrm{Mn}, \mathrm{Fe})-\mathrm{Y}-(\mathrm{Sb}, \mathrm{As})-(\mathrm{Nb}, \mathrm{Ti})$ oxide. In contrast to most Group 1 metapegmatites, Group 2 pegmatites occur relatively near the edge of the Tysfjord basement window, and, thus, immediately below the now eroded thrust (Fig. 1).

\section{Methods}

\section{Sampling}

For this study, we selected columbite group minerals for $\mathrm{U}-\mathrm{Pb}$ dating from the mineral collection of the Natural History Museum of Oslo (samples Hundholmen MIN 27459 and Tiltvika MIN 17265). Specimens were also collected from the active Nedre Øyvollen underground mine at Drag and from the Tjeldøya pegmatite (with both columbite and zircon). The columbite sample from the Tennvatn pegmatite tite with an allanite-(Ce) phenoclast (arrow). The dark layers consist of magnetite and biotite. C Dyke-like, up to $1 \mathrm{~m}$ wide Group 2 amazonite pegmatite at Hellmobotn (arrow). D Amazonite-tourmalinequartz assemblage of the Group 2 Tjeldøya pegmatite

was provided by the mineral collector Astrid Haugen. In addition, two Tysfjord granite gneiss varieties, one next to the Jennyhaugen metapegmatite at Drag and one at Finnøy Island next to the Karlsøy metapegmatite, were sampled for zircon dating and for whole rock analysis.

To estimate the composition of Group 1 metapegmatites, three 5-kg samples were taken from the medium- to coarsegrained wall zone of the Jennyhaugen metapegmatite. The wall zone of pegmatites crystallized first. Therefore, it may better represent the initial composition of the pegmatite melt, although the wall zone may contain lower concentrations of incompatible elements than more evolved zones (e.g., Müller et al. 2021).

\section{Electron probe microanalysis}

The compositions of columbite-group minerals were determined using a Cameca SX100 electron microprobe at the 


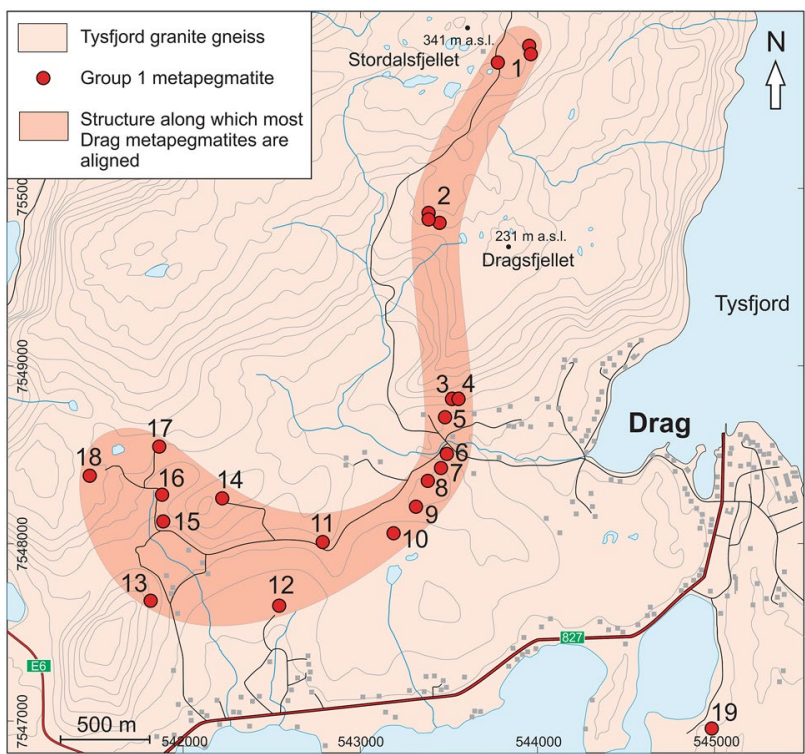

Fig. 4 Geological map showing the metapegmatite locations in the vicinity of the village Drag. Pegmatite mines (names according to Åmli 1975): 1, Fjellgruvene; 2, Nekkateltgruvene; 3, Øvre Øyvollen; 4, Perjongruva; 5, Nedre Øyvollen; 6, Grønnhola; 7, Kvartsbrudd Øst; 8, Burma; 9, Jennyhaugen; 10, Sumpa; 11, Lillebakkgruvene; 12, Lillebakkmyra; 13, Bennygruva; 14, Svenskgruva; 15, Nedre Lapplægret; 16, Øvre Lapplægret; 17, Kvartsbrudd Nordre; 18, Vestre Trettbakken; 19, Hammondgruva

Natural History Museum of London. The samples were prepared as surface-polished, one-inch epoxy mounts. Instrument beam conditions were $20 \mathrm{kV}$ and $20 \mathrm{nA}$ with a $1 \mu \mathrm{m}$ spot size. The Cameca supplied PAP matrix correction was used. Peak overlaps were corrected prior to matrix correction for the most severe peak overlaps.

\section{TIMS U-Pb dating of columbite-group minerals}

Columbite-group minerals were dated at GFZ German Research Centre for Geosciences, Potsdam, Germany using the sample preparation procedures described in Romer and Smeds (1996) and Baumgartner et al. (2006). Isotope ratios were determined with a Triton multi-collector mass spectrometer using Faraday collectors and ion counting, operated in static multi-collection mode. The analytical results are shows in (Table 1).

All samples were leached. The rationale behind the leaching and annealing procedures is the following: columbitegroup minerals commonly have elevated $U$ contents (a few hundred to several thousand ppm) that may be heterogeneously distributed within the mineral and that with time lead to metamictization beginning in particularly U-rich domains (Romer et al. 2007). Metamict domains may experience significant redistribution of $\mathrm{U}$ and $\mathrm{Pb}$, leading on the small scale to overall loss or gain of $\mathrm{U}$ and $\mathrm{Pb}$. Locally there may also be additions of common $\mathrm{Pb}$. To avoid problems related to such open system behaviour of the $\mathrm{U}-\mathrm{Pb}$ system in columbite-group minerals, selected fragments were leached in $20 \% \mathrm{HF}$ ( $20 \mathrm{~min}$ at $70{ }^{\circ} \mathrm{C}$ ), followed by washing steps using $6 \mathrm{~N} \mathrm{HCl}$ and $7 \mathrm{~N} \mathrm{HNO}_{3}$, respectively (20 min each at $70{ }^{\circ} \mathrm{C}$ ). This leaching procedure using different acids typically removes fracture fills and inclusions of quartz, feldspar, sulphides, and metamict domains. The selective dissolution procedure usually results in higher ${ }^{206} \mathrm{~Pb} /{ }^{204} \mathrm{~Pb}$ values (Romer and Wright 1992) as carriers of common $\mathrm{Pb}$ (feldspar and sulphide inclusions) are preferentially removed and in favourable cases yields concordant data (Romer and Smeds 1996; Lindroos et al. 1996). The higher common $\mathrm{Pb}$ contents in some samples largely are due to the larger size of the fragments of the columbite-group minerals used, essentially reflecting the less efficient removal of damaged sections in larger fragments. Incomplete removal of metamict domains may preferentially mobilize $\mathrm{Pb}$ or $\mathrm{U}$ and, thus, result in laboratory induced normal or reverse discordance. Incompletely leached columbite-group minerals typically develop a brown stain during the final leaching step, rather than metallic luster (Romer 2003). Some columbite-group minerals from Tysfjord (meta-)pegmatites showed such anomalous leaching behaviour, as repeated leaching did not produce surfaces with metallic luster or dissolved the mineral completely. This behaviour reflects that the mineral is almost completely metamict.

To prevent complete sample dissolution during the sample leaching procedure, two samples were annealed at $650{ }^{\circ} \mathrm{C}$ for $60 \mathrm{~min}$ before leaching. Annealing prevents complete dissolution of the mineral during the later leaching procedure, but preserves disturbances originating from element mobility in the metamict domains. Thus, annealed samples do not produce precise ages, but tend to produce scattered data about a Discordia. The Discordia intercept ages of annealed samples represent a good estimate for the age, but should not be considered to be accurate.

\section{TIMS U-Pb dating of zircon}

The samples were crushed, ground and passed over a Wilfley table before heavy minerals were separated using standard heavy liquid and magnetic techniques at the University of Oslo (except from the Tjeldøya zircon, see above). Zircons were selected under an optical microscope, annealed for ca. $72 \mathrm{~h}$ at ca. $900^{\circ} \mathrm{C}$ and chemically abraded with HF in a highpressure dissolution vessel at ca. $195{ }^{\circ} \mathrm{C}$ for $12 \mathrm{~h}$ (Huyskens et al. 2016; Mattinson 2005). The zircons grains chosen for analyses were spiked with the ${ }^{205} \mathrm{~Pb}_{-}{ }^{233-235} \mathrm{U}$ EARTHTIME (ET) tracer (Condon et al. 2015). After spiking, zircon samples were dissolved in $\mathrm{HF}\left(+\mathrm{HNO}_{3}\right)$ at $>48 \mathrm{~h}$ in Teflon micro capsules enclosed in a Parr type Teflon bomb and the solutions were subsequently passed through column 


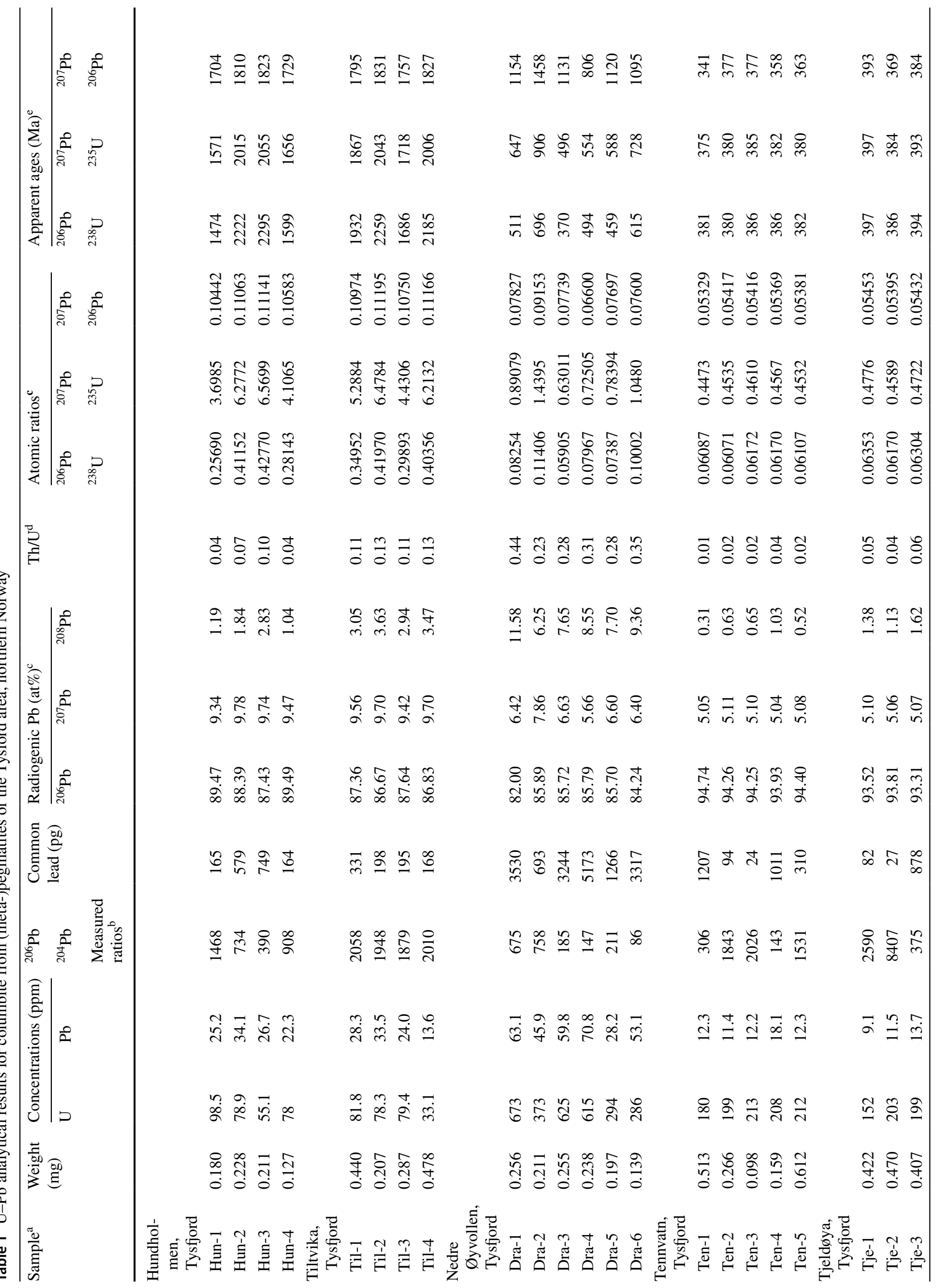


chemistry (separating $\mathrm{U}$ and $\mathrm{Pb}$ from REE's and other ionisation inhibiting elements). The solutions were loaded on zone refined Re filaments and measured on a Finnigan MAT262 thermal ionisation mass spectrometer (TIMS). The mass spectrometric techniques used are presented in detail in Ballo et al. (2019), with upgraded laboratory parameters: $\mathrm{Pb}$ blank generally $<1.2 \mathrm{pg}$ with a composition of ${ }^{206} \mathrm{~Pb} /{ }^{204} \mathrm{~Pb}=18.04 \pm 0.40 ;{ }^{207} \mathrm{~Pb} /{ }^{204} \mathrm{~Pb}=15.22 \pm 0.30$; ${ }^{208} \mathrm{~Pb} /{ }^{204} \mathrm{~Pb}=36.67 \pm 0.50$. The raw data were cleaned using Tripoli (Bowring et al. 2011) and further reduced including calculation of analytical errors and corrections (including Th-corrections, assuming $\mathrm{Th} / \mathrm{U}$ in the magma of 3) were incorporated and propagated using an Excel macro based on published algorithms (Schmitz and Schoene 2007). Concordia diagrams were generated and intercept ages were calculated using ISOPLOT (Ludwig 2003) with specified decay constants (Jaffey et al. 1971). The ages are reported with $\pm x / y / z$ errors, where $x$ only includes the analytical uncertainties, $y$ is the error including the analytical and tracer calibration uncertainties and $z$ is the error including the analytical uncertainties, tracer uncertainties and uncertainty in the decay constant (Table 2).

\section{Results}

\section{Chemistry of the Tysfjord granite gneiss and Group 1 metapegmatites}

Bulk rock analyses were performed on the two Tysfjord granite gneiss samples from Karlsøy and Jennyhaugen, of which zircon was separated for dating. In addition, published whole rock data of other granite localities of the northern Tysfjord window and of one Group 1 metapegmatite wall zone composition are considered in the following (Romer et al. 1992; Müller 2011). The complete data set is provided in the Supplementary Material Table SM1.

Generally, the Tysfjord granite gneiss in the northern Tysfjord window is metaluminous to peraluminous (A/ $\mathrm{CNK}=0.9-1.1$ ) rocks with low $\mathrm{TiO}_{2}$ (mean 0.39 wt.\%), $\mathrm{Sr}$ (mean $92 \mathrm{ppm}$ ) and $\mathrm{P}_{2} \mathrm{O}_{5}$ (mean 0.08 wt.\%) (Fig. 5). The fractionated granites are enriched in $\mathrm{K}, \mathrm{F}, \mathrm{Rb}, \mathrm{Th}, \mathrm{U}, \mathrm{Nb}$, $\mathrm{Y}$, REE, Hf, and Zr. Fluorine concentrations reach up to 0.45 wt.\%. The older TIB-1 granites show little chemical variation, whereas the more fractionated TIB-2 granites, characterised by high $1 / \mathrm{TiO}_{2}$ ratios (Fig. 5), show variable chemical compositions with enrichment of LREE, Th, U, $\mathrm{Nb}$, Ta, Hf and Zr. The REE patterns show a strong enrichment of LREE relative to HREE and a moderate negative $\mathrm{Eu}$ anomaly, which is more pronounced in the TIB-2 than in TIB-1. Due to their elevated REE, $\mathrm{Zr}$ and Nb contents $(\mathrm{REE}+\mathrm{Zr}+\mathrm{Nb}>350 \mathrm{ppm})$, granite samples from Jennyhaugen, Karlsøy, Hundholmen and Kjerrfjell and most of the 
Table $2 \mathrm{U}-\mathrm{Pb}$ analytical results for zircon from granite gneisses and pegmatites of the Tysford area, northern Norway

\begin{tabular}{|c|c|c|c|c|c|c|c|c|c|c|c|c|c|c|c|c|}
\hline \multirow{3}{*}{$\begin{array}{l}\text { Sample } \\
\text { (a) }\end{array}$} & \multicolumn{2}{|c|}{$\begin{array}{l}\text { Composi- } \\
\text { tion }\end{array}$} & \multicolumn{10}{|c|}{ Radiogenic isotope ratios } & \multicolumn{4}{|c|}{ Isotopic ages } \\
\hline & \multirow{2}{*}{$\begin{array}{l}\text { Th } \\
\mathrm{U} \\
\text { (b) }\end{array}$} & \multirow{2}{*}{$\begin{array}{l}\mathrm{Pb}_{\mathrm{c}} \\
(\mathrm{pg}) \\
\text { (c) }\end{array}$} & \multirow{2}{*}{$\begin{array}{l}{ }^{206} \mathrm{~Pb} \\
{ }^{204} \mathrm{~Pb} \\
\text { (d) }\end{array}$} & \multicolumn{2}{|l|}{${ }^{207} \mathrm{~Pb}$} & \multicolumn{2}{|l|}{${ }^{207} \mathrm{~Pb}$} & \multicolumn{2}{|l|}{${ }^{206} \mathrm{~Pb}$} & \multirow[t]{2}{*}{ Corrr Coef } & \multicolumn{2}{|l|}{${ }^{207} \mathrm{~Pb}$} & \multicolumn{2}{|l|}{${ }^{207} \mathrm{~Pb}$} & \multicolumn{2}{|l|}{${ }^{206} \mathrm{~Pb}$} \\
\hline & & & & $\begin{array}{l}{ }^{206} \mathrm{~Pb} \\
\text { (e) }\end{array}$ & $\begin{array}{l}\% \text { err } \\
\text { (f) }\end{array}$ & $\begin{array}{l}{ }^{235} \mathrm{U} \\
\text { (e) }\end{array}$ & $\begin{array}{l}\% \text { err } \\
\text { (f) }\end{array}$ & $\begin{array}{l}{ }^{238} \mathrm{U} \\
\text { (e) }\end{array}$ & $\begin{array}{l}\% \text { err } \\
\text { (f) }\end{array}$ & & $\begin{array}{l}{ }^{206} \mathrm{~Pb} \\
(\mathrm{~g})\end{array}$ & $\begin{array}{l} \pm \\
\text { (f) }\end{array}$ & $\begin{array}{l}{ }^{235} \mathrm{U} \\
(\mathrm{g})\end{array}$ & $\begin{array}{l} \pm \\
\text { (f) }\end{array}$ & $\begin{array}{l}{ }^{238} \mathrm{U} \\
(\mathrm{g})\end{array}$ & $\begin{array}{l} \pm \\
\text { (f) }\end{array}$ \\
\hline \multicolumn{17}{|c|}{2922 Jennyhaugen, Tysfjord granite } \\
\hline $610 / 1$ & 0.31 & 2.39 & 17,742 & 0.106552 & 0.043 & 3.859 & 0.15 & 0.26268 & 0.13 & 0.962 & 1741.24 & 0.79 & 1605.2 & 1.2 & 1503.5 & 1.8 \\
\hline $610 / 2$ & 0.33 & 3.30 & 3056 & 0.106669 & 0.065 & 3.924 & 0.16 & 0.26680 & 0.11 & 0.950 & 1743.3 & 1.2 & 1618.6 & 1.3 & 1524.5 & 1.5 \\
\hline $610 / 3$ & 0.40 & 2.06 & 8798 & 0.106818 & 0.094 & 3.933 & 0.14 & 0.267074 & 0.088 & 0.726 & 1745.8 & 1.7 & 1620.6 & 1.1 & 1525.9 & 1.2 \\
\hline $610 / 4$ & 0.25 & 1.05 & 791 & 0.107091 & 0.163 & 4.077 & 0.30 & 0.27614 & 0.14 & 0.978 & 1750.5 & 3.0 & 1649.8 & 2.4 & 1571.9 & 2.0 \\
\hline $610 / 5$ & 0.27 & 1.26 & 292 & 0.100375 & 0.553 & 2.890 & 0.68 & 0.20881 & 0.17 & 0.832 & 1631 & 10 & 1379.3 & 5.2 & 1222.5 & 1.9 \\
\hline \multicolumn{17}{|c|}{3122 Karlsøy, Tysfjord granite } \\
\hline $610 / 6$ & 0.32 & 1.68 & 1363 & 0.101868 & 0.089 & 2.905 & 0.13 & 0.206859 & 0.070 & 0.799 & 1658.4 & 1.7 & 1383.3 & 1.0 & 1212.06 & 0.78 \\
\hline $610 / 7$ & 0.26 & 2.04 & 294 & 0.103281 & 0.790 & 3.399 & 0.96 & 0.23871 & 0.185 & 0.957 & 1684 & 15 & 1504.2 & 7.6 & 1380.0 & 2.3 \\
\hline $610 / 8$ & 0.49 & 4.93 & 4454 & 0.109732 & 0.047 & 4.705 & 0.12 & 0.310958 & 0.095 & 0.934 & 1794.97 & 0.86 & 1768.1 & 1.0 & 1745.4 & 1.5 \\
\hline $610 / 9$ & 0.50 & 1.63 & 20,145 & 0.109192 & 0.042 & 4.585 & 0.14 & 0.30457 & 0.119 & 0.958 & 1785.98 & 0.77 & 1746.6 & 1.2 & 1713.9 & 1.8 \\
\hline $610 / 10$ & 0.42 & 1.41 & 7324 & 0.107983 & 0.072 & 4.218 & 0.21 & 0.28328 & 0.185 & 0.936 & 1765.7 & 1.3 & 1677.5 & 1.7 & 1607.9 & 2.6 \\
\hline \multicolumn{17}{|c|}{ Tjeldøya pegmatite } \\
\hline $616 / 10$ & 0.04 & 0.86 & 29,946 & 0.054594 & 0.16 & 0.4729 & 0.27 & 0.062817 & 0.20 & 0.804 & 395.6 & 3.6 & 393.16 & 0.87 & 392.74 & 0.77 \\
\hline
\end{tabular}

${ }^{\text {a }}$ Single zircon fraction chemically abraded (Mattinson, 2005)

${ }^{\mathrm{b}} \mathrm{Model} \mathrm{Th} / \mathrm{U}$ ratio iteratively calculated from the radiogenic ${ }^{208} \mathrm{~Pb} /{ }^{206} \mathrm{~Pb}$ ratio and ${ }^{206} \mathrm{~Pb} /{ }^{238} \mathrm{U}$ age

${ }^{\mathrm{c}} \mathrm{Pb}$ c represents common $\mathrm{Pb}$

${ }^{\mathrm{d}}$ Measured ratio corrected for spike and fractionation only. Pb fractionation estimated at $0.16 \pm 0.03 \% / \mathrm{a} . \mathrm{m} . \mathrm{u}$. for SEM analyses, based on repeated analysis of NBS982

${ }^{\mathrm{e}}$ Corrected for fractionation, spike, and common $\mathrm{Pb}$; up to 2 pg of common $\mathrm{Pb}$ was assumed to be procedural blank: ${ }^{206} \mathrm{~Pb} /{ }^{204} \mathrm{~Pb}=18.07 \pm 0.30 \%$;

${ }^{207} \mathrm{~Pb} /{ }^{204} \mathrm{~Pb}=15.57 \pm 0.20 \% ;{ }^{208} \mathrm{~Pb} /{ }^{204} \mathrm{~Pb}=37.85 \pm 0.30 \%$ (all uncertainties 1 -sigma). Excess over blank was assigned to initial common $\mathrm{Pb}$, using the Stacey and Kramers (1975) two-stage $\mathrm{Pb}$ isotope evolution model at the nominal sample age

${ }^{\mathrm{f}}$ Errors are 2-sigma, propagated using the algorithms of Schmitz and Schoene (2007)

${ }^{\mathrm{g}}$ Calculations are based on the decay constants of Jaffey et al. (1971). ${ }^{206} \mathrm{~Pb} /{ }^{238} \mathrm{U}$ and ${ }^{207} \mathrm{~Pb} /{ }^{206} \mathrm{~Pb}$ ages corrected for initial disequilibrium in ${ }^{230} \mathrm{Th} /{ }^{238} \mathrm{U}$ using $\mathrm{Th} / \mathrm{U}[\mathrm{magma}]=3$

samples from Hellmobotn classify as A-type granites. Some TIB-1 granites and some of the less fractionated TIB-2 granites from Hellmobotn have I-type characteristics.

The average major element composition of the wall zone of the Jennyhaugen metapegmatite resembles that of the most evolved granite gneiss samples (Fig. 5). The major differences between metapegmatite and granite gneisses are the strong depletion in LREE and the pronounced negative $\mathrm{Eu}$ anomaly in the metapegmatites.

\section{Tysfjord granite gneiss $\mathrm{U}-\mathrm{Pb}$ zircon dating}

\section{Jennyhaugen (sample 2922)}

Five single zircon crystals were analysed from Tysfjord granite gneiss exposed next to the Jennyhaugen metapegmatite. All grains were euhedral, prismatic with a medium to high aspect ratio (1:3-1:5) and with relatively abundant inclusions. The zircon crystals display varying degrees of metamictisation, with some grains having heavily metamict domains. Cathodoluminescence images of zircon crystals show complex zonation with a mixture of sector zoning and oscillatory zoning, indicating recrystallisation during a metamorphic event. All analysed zircon crystals (analyses 610/1-610/5), even those with simple zonation, and a zircon tip with faint sector zonation are discordant (Table 2; Fig. 6). With the exception of the zircon tip (610/5), the zircon analyses project towards an upper intercept age of c. $1772 \pm 9 \mathrm{Ma}(2 \sigma ; \mathrm{MSWD}=2.8)$. Using only the zircon tip (610/5) and the least discordant zircon prism (610/4), the data yield an upper intercept age of $1801 \pm 6 \mathrm{Ma}(2 \sigma)$. The remaining analyses plot below this two-point discordia line, reflecting Pb-loss/recrystallization during a late Caledonian event and $\mathrm{Pb}$-loss from metamict domains. 

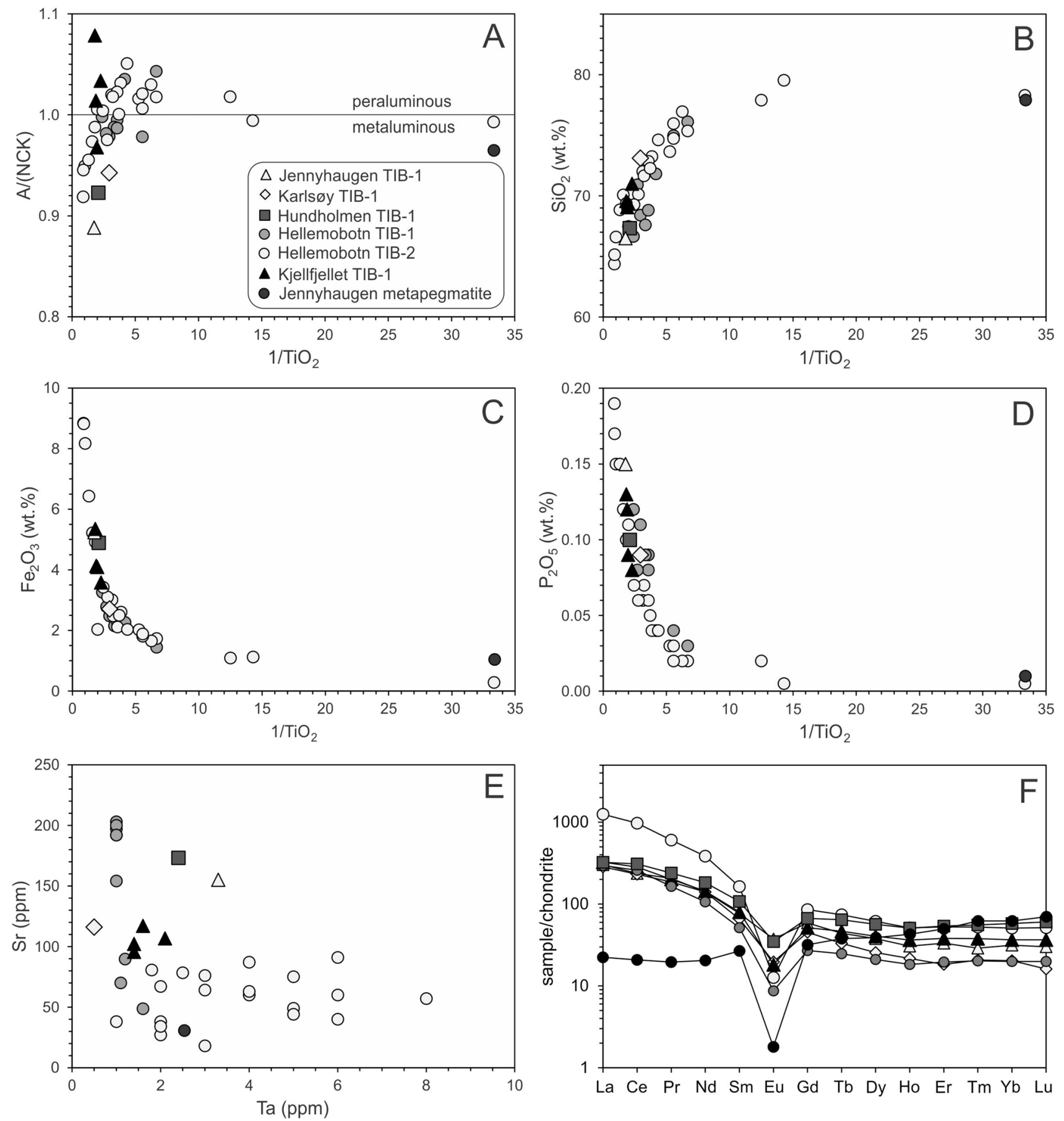

Fig. 5 Variation diagrams, using $1 / \mathrm{TiO}_{2}$ as differentiation index, for selected major and trace element components of Tysfjord granite gneiss and the Jennyhaugen metapegmatite (wall zone) exposed in the northern Tysfjord window

\section{Karlsøy (sample 3122)}

Five single, euhedral zircon prisms were analysed from this sample (analyses 610/6 to 610/10). Two zircon crystals have a medium aspect ratio (1:3 to $1: 4)$ and are highly metamict (610/6 and 610/7). After chemical abrasion, only the outer parts of the zircon crystals were left. These grains display faintly visible oscillatory zonation in the metamict central parts of the grains and either faint oscillatory zonation or homogeneous zones at the margin. The remaining zircon crystals have a medium to high aspect ratio (1:3-1:5) and show oscillatory to sector zoning. All analyses are discordant with the oscillatory zoned, high aspect ratio zircon crystals being the least discordant ones and the metamict zircon 
crystals being the most discordant ones. The analyses do not define a single discordia line, indicating that two or more post protolith crystallisation $\mathrm{Pb}$-loss events or recrystallization events affected the zircons. The least discordant analysis (610/8) still constrains the protolith age. If analysis 610/8 is combined with the youngest, metamict zircon, an upper intercept age of $1804.7 \pm 1.0 \mathrm{Ma}(2 \sigma)$ is obtained, with a lower intercept age of $433.7 \pm 4.5 \mathrm{Ma}(2 \sigma)$. The upper intercept age is considered the best estimate for the protolith age of this phase of the Tysfjord granite gneiss, while the lower intercept age corresponds to the age of Scandian metamorphism (e.g., Grimmer et al. 2015).

The best estimates of protolith ages for both Tysfjord granite gneisses, $1801 \pm 6 \mathrm{Ma}$ (Jennyhaugen) and 1804.7 + 1.0 Ma (Karlsøy), cannot resolve age differences between the two phases and, thus, a common age of ca. $1805 \mathrm{Ma}$ is suggested. Based on the zircon data, the timing of Caledonian metamorphism cannot be resolved. High-temperature metamorphism during the Caledonian Orogeny is, however, here interpreted to result in zircon recrystallisation that led to the observed post-Scandian $\mathrm{Pb}$ mobilisation.

\section{Tjeldøya pegmatite zircon $\mathrm{U}-\mathrm{Pb}$ dating}

A fragment broken off from one large, pristine, moderately metamict zircon from the Tjeldøya pegmatite was analysed (Fig. 6D). The zircon has a low Th/U-ratio of 0.043 and is concordant at $392.87 \pm 0.84 \mathrm{Ma}(2 \sigma$; MSWD (of concordance) $=0.97$ ), which we interpret to represent the crystallisation of zircon from the pegmatite melt and, hence, the emplacement of the pegmatite.

\section{Tysfjord (meta-)pegmatite columbite-group mineral chemistry}

The complete list of major and minor element concentrations of columbite-group minerals selected for dating is provided in the Supplementary Material Table SM2. The dated columbite-group minerals plot as columbite- $(\mathrm{Fe})$ and columbite-(Mn) according to the $\mathrm{Mn} /(\mathrm{Mn}+\mathrm{Fe})$ versus $\mathrm{Ta} /$ $(\mathrm{Ta}+\mathrm{Nb})$ discrimination diagram of Černý (1989) (Fig. 7). Some Tysfjord columbite crystals are among the lowest Ta columbite-tantalite group minerals from Svecofennian NYF pegmatites. Columbite from undeformed Group 2 pegmatites has, however, higher $\mathrm{Ta} /(\mathrm{Ta}+\mathrm{Nb})$ ratios due to higher $\mathrm{Ta}$ and lower $\mathrm{Nb}$ than Group 1 columbite and shows little variation in $\mathrm{Mn} /(\mathrm{Mn}+\mathrm{Fe})$. In contrast, Group 1 columbite is characterised by highly variable $\mathrm{Mn} /(\mathrm{Mn}+\mathrm{Fe})$ ratios and similar $\mathrm{Ta} /(\mathrm{Ta}+\mathrm{Nb})$ ratios. Based on the $\mathrm{Nb}$ and $\mathrm{Ta}$ contents, Group 1 metapegmatites and Group 2 pegmatites are well distinguishable. The $\mathrm{Sn}, \mathrm{W}, \mathrm{Ti}$, and $\mathrm{Zr}$ contents of both groups are low, and REE, Y, and $\mathrm{U}$ are commonly below the limit of detection. Only columbite-(Mn) from Tjeldøya has
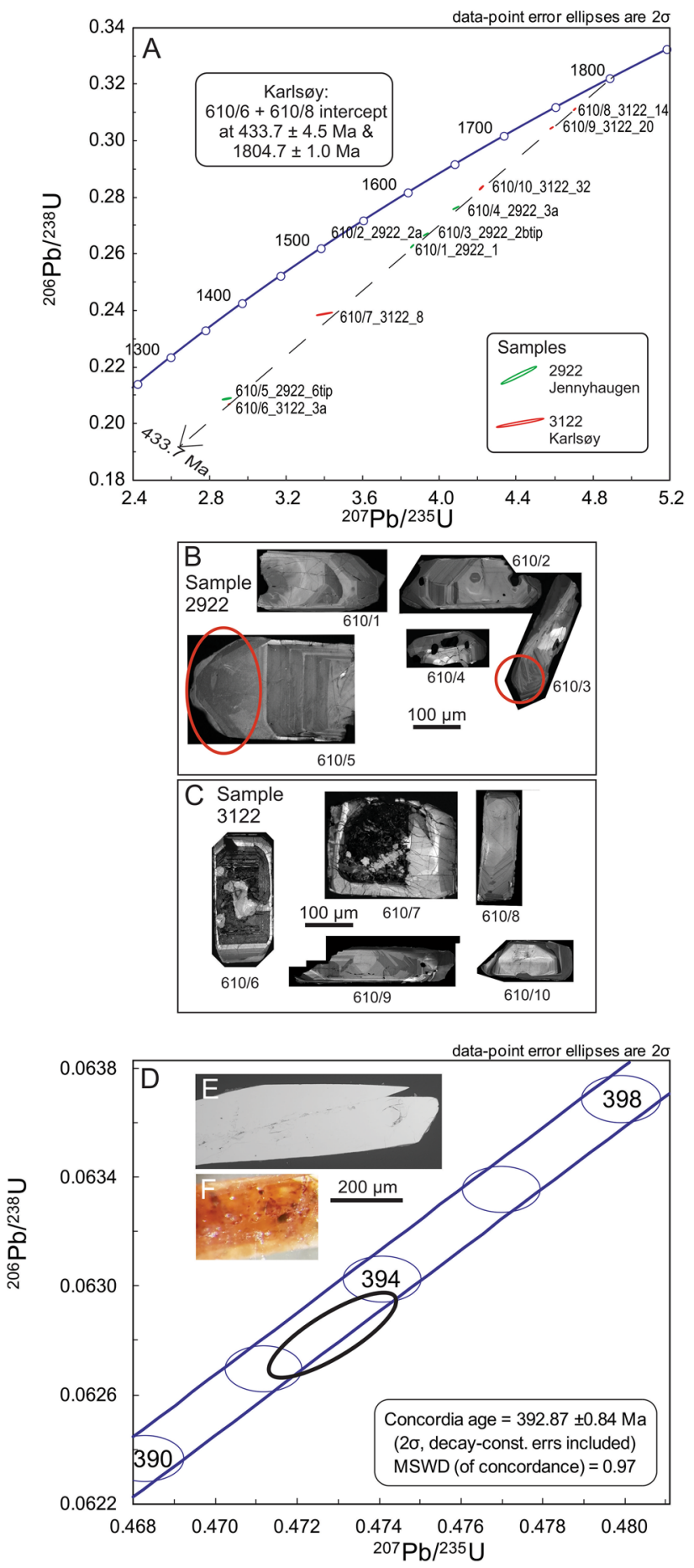

Fig. 6 A Concordia diagram for zircon from two Tysfjord granite gneisses (samples 2922 and 3122) analysed in this study. Error ellipses are plotted with $2 \sigma$ absolute errors (including decay constant errors). Sample locations are shown in Fig. 1. B and C SEM-CL images of analysed zircon crystals of samples 2922 and 3122. D Concordia diagram displaying the analysis of a fragment of the Tjeldøya pegmatite zircon. E BSE image of the analysed zircon. F Optical image of the central part of the zircon. Note the brown color and slightly foggy appearance reflecting metamictisation, and the presence of inclusions. Sample location is shown in Fig. 1 


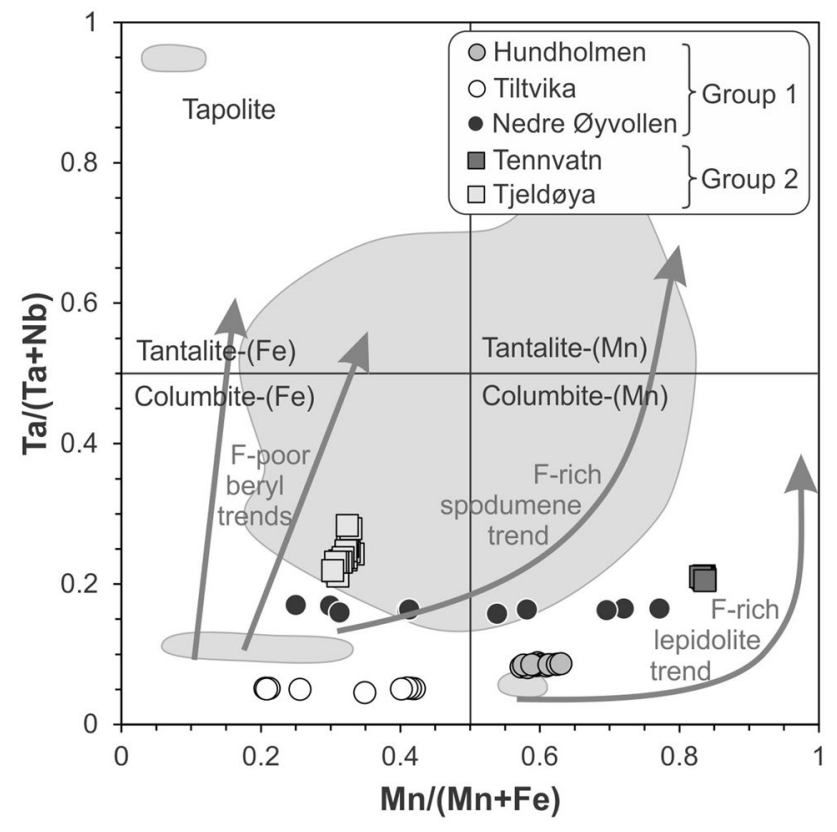

Fig.7 Quadrilateral classification diagram (according to Černý 1989) shows the chemical variation of columbite-group minerals used for dating of Tysfjord (meta-)pegmatites. The grey fields indicate the compositional variation of columbite-group minerals from Svecofennian NYF pegmatites of Sweden and southern Finland based on data from Romer and Smeds (1994, 1997), Lindroos et al. (1996), Romer (1997), and Müller et al. (2017). The chemical evolution trends are according to Černý (1989)

elevated Ti concentrations. The very low $\mathrm{Sn}$ and $\mathrm{W}$ contents (see also Melcher et al. 2016) seems to reflect the limited availability of Sn and W, rather than the restricted possibility to incorporate them (see also Tysfjord granite gneiss chemistry).

\section{Tysfjord (meta-)pegmatite U-Pb columbite dating}

Data from the five dated columbite samples fall on a discordant trend between early Proterozoic and early Paleozoic ages. Two samples give concordant data with early Paleozoic ages, whereas the data from three Paleoproterozoic columbite samples define a discordant trend (Fig. 8). The data show that there are two crystallization events of columbitegroup minerals.

\section{Hundholmen (annealed)}

Four fragments of a columbite crystal from the Hundholmen metapegmatite have been analyzed. The samples were annealed and leached before dissolution. The leached samples are characterized by relatively low U (55-99 ppm) and $\mathrm{Pb}(20-34 \mathrm{ppm})$ contents, which possibly indicate that during recrystallization of columbite, $\mathrm{U}$ was preferentially incorporated in a separate phase that readily dissolved during leaching or the leaching could have non-systematically fractionated $\mathrm{U}$ and $\mathrm{Pb}$, resulting in variable degrees of $\mathrm{U}$ and $\mathrm{Pb}$ loss. All fragments had relatively high common $\mathrm{Pb}$ contents of $0.92-3.6 \mathrm{ppm}$, resulting in relatively low measured ${ }^{206} \mathrm{~Pb} /{ }^{204} \mathrm{~Pb}$ ratios (Table 1). The analytical results define a discordant trend that intersects the concordia line at $1755.9 \pm 4.9 \mathrm{Ma}(2 \sigma, \mathrm{MSWD}=0.16)$ and $404 \pm 28 \mathrm{Ma}$ $(2 \sigma)$. The upper intercept is interpreted as the age of columbite crystallization and, thus, pegmatite emplacement at ca. $1756 \mathrm{Ma}$, whereas the lower intercept reflects recrystallization and/or $\mathrm{Pb}$ loss during the Caledonian orogeny. The date show clearly, that the columbite is of Paleoproterozoic age and recrystallized during the Caledonian orogeny.

\section{Tiltvika (annealed)}

Columbite from Tiltvika was annealed before analysis. The leached four fragments are characterized by relatively low $\mathrm{U}$ (33-82 ppm) and $\mathrm{Pb}$ (14-34 ppm), have common $\mathrm{Pb}$ contents of $0.35-0.96 \mathrm{ppm}$, and relatively radiogenic ${ }^{206} \mathrm{~Pb} /{ }^{204} \mathrm{~Pb}$ ratios (Table 1). The data plot to both sides of the concordia and define a discordant trend that intercepts at $1772.4 \pm 2.9 \mathrm{Ma}(2 \sigma, \mathrm{MSWD}=0.47)$ and $437 \pm 24 \mathrm{Ma}(2 \sigma)$ (Fig. 8A). The lower intercept reflects recrystallization and/ or $\mathrm{Pb}$ loss. As for the Hundholmen metapegmatite, we interpret the upper intercept as the age of pegmatite emplacement and the lower intercept as evidence for recrystallization during the Caledonian orogeny.

\section{Nedre Øyvollen}

We analyzed six fragments of a columbite crystal from the Drag metapegmatite field. The samples were not annealed before leaching. All fragments are characterized by high $\mathrm{U}$ contents (373-625 ppm). All fragments have high common $\mathrm{Pb}$ contents (3.3-23.9 ppm) and, therefore, are characterized by low measured ${ }^{206} \mathrm{~Pb} /{ }^{204} \mathrm{~Pb}$ ratios (Table 1). The analytical data scatter do not define a discordant trend. In a diagram showing the data from the Drag columbite together with the data from the Hundholmen and Tiltvika columbites, the Drag data plot close to the discordant trend defined by the Hundholmen and Tiltvika columbites (Fig. 8A). The offset of some of the Drag data toward the origin of the diagram reflects post-Caledonian $\mathrm{Pb}$ loss. Columbite from Drag does not permit an age interpretation. Because columbite from Drag, Hundholmen, and Tiltvika show similar data distribution, we interpret the data of columbite from Drag to reflect Caledonian recrystallization of a Paleoproterozoic columbite, which lost $\mathrm{Pb}$ due to pre-Caledonian metamictisation. 
Fig. $8 \mathrm{U}-\mathrm{Pb}$ data for leached columbite-group minerals from Tysfjord (meta-)pegmatite localities Hundholmen, Tennvatn and Tjeldøya. Analytical data are shown at $2 \sigma$ uncertainties. Data from Table 1; for discussion see text. In $\mathbf{A}, \mathrm{Pb} / \mathrm{U}$ ratios of an allanite-(Ce) sample from the Stetind metapegmatite determined by Hetherington et al. (2021) are added. The allanite-(Ce) data indicate an inherited pre-Caledonian age

\section{Tennvatn}

The U-Pb data of five fragments from a columbite crystal from the Tennvatn pegmatite fall on or slightly above the Concordia. The uncertainties do not all overlap within uncertainties. The various fragments have similar U contents (180-213 ppm), but very variable common $\mathrm{Pb}$ contents $(0.35-6.3 \mathrm{ppm})$, resulting in a broad range of measured ${ }^{206} \mathrm{~Pb} /{ }^{204} \mathrm{~Pb}$ rations (Table 1 ). The data show excess scatter and the average of the five ${ }^{206} \mathrm{~Pb} /{ }^{238} \mathrm{U}$ ages yields an age of ca. $383 \mathrm{Ma}$ (Fig. 8B). This age is interpreted to date the crystallization of columbite and the emplacement of the pegmatite.

\section{Tjeldøya}

Five of the six analysed columbite fragments from the Tjeldøya pegmatite are concordant and overlap within analytical uncertainty. The remaining fragment also is concordant, but yields a slightly younger apparent age. Most fractions have low common $\mathrm{Pb}$ contents (0.06-0.46 ppm), but one sample has $2.2 \mathrm{ppm}$ common $\mathrm{Pb}$, which may be due to a sulphide or feldspar inclusion. Although there is significant scatter between the individual data points, a weighted average of five overlapping ${ }^{206} \mathrm{~Pb} /{ }^{238} \mathrm{U}$ ages gives an age of ca. $397 \mathrm{Ma}$. This age is similar to the zircon concordia age $(392.87 \pm 0.84 \mathrm{Ma})$ and corroborates the interpretation of the latter age as dating the emplacement of the pegmatite. The youngest columbite analysis is equal in age, within uncertainty, to the zircon, and the slightly older ages of the remaining concordant columbite analyses probably reflects that the actual common $\mathrm{Pb}$ composition was slightly more radiogenic than the $\mathrm{Pb}$ isotopic composition used for the common $\mathrm{Pb}$ correction. Nevertheless, the data shows that both the columbites and zircon crystallized during emplacement of the pegmatite. Corresponding ages of independent $\mathrm{U}-\mathrm{Pb}$ columbite and $\mathrm{U}-\mathrm{Pb}$ zircon dating of the Tjeldøya pegmatite prove the robustness of the applied methods.

\section{Discussion}

Our data demonstrate two regional pegmatite-forming events in the same area and in the same lithological unit. These are related to two orogens: Late Svecofennian Group 1
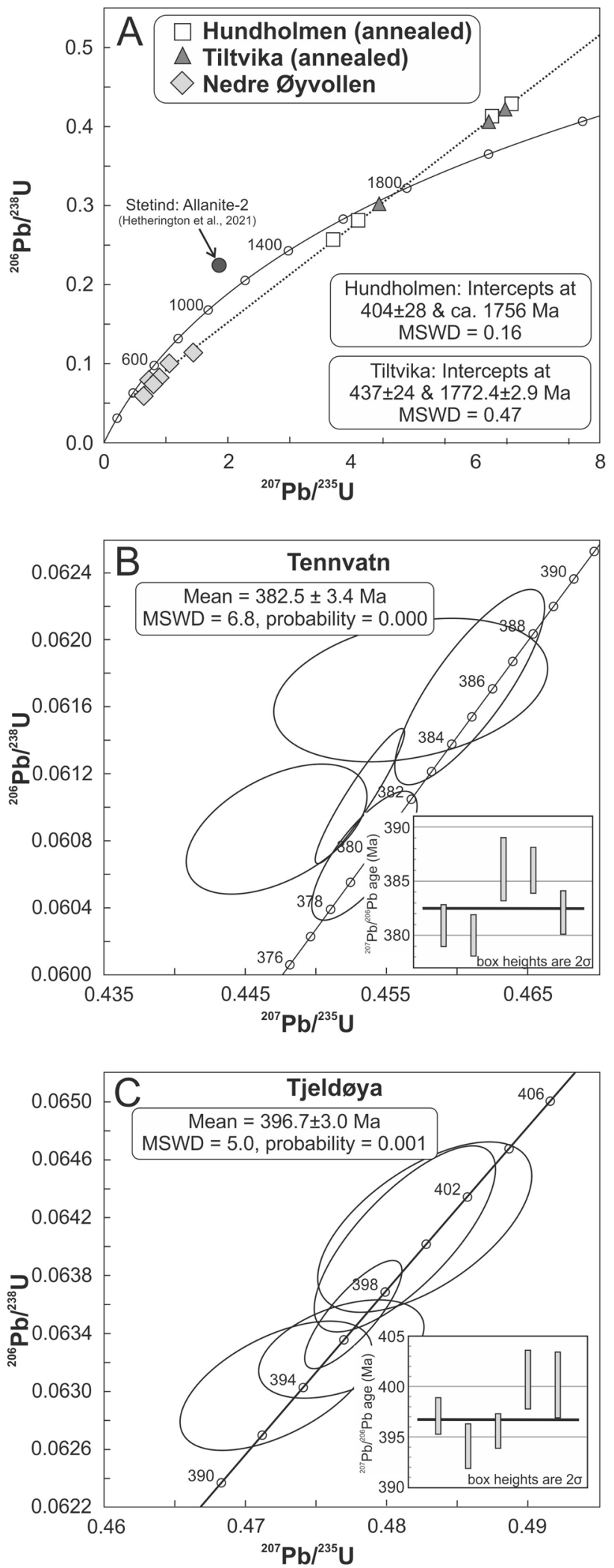

metapegmatites (1755-1772 Ma) and late Caledonian Group 2 pegmatites (400-379 Ma). In the following, the two events 
and their implications for the orogenic evolution and the pegmatite formation in general are discussed.

\section{Svecofennian magmatism and related Group 1 metapegmatite formation in the Tysfjord area}

The Svecofennian granite suite of the northern Tysfjord window is dominated by the older TIB-1 granites as shown by our and previously published data (Romer et al. 1992 and this study). Crystallization ages of these granites vary from 1781 to $1809 \mathrm{Ma}$. Our data from the northern Hamarøy area (Drag-Finnøy; zircon U-Pb 1804.7+3.9/-10.9 Ma), where the majority of Group 1 metapegmatites occur, also fall in this age range. Occurrences of TIB-2 granites, which form relatively small bodies (several hundred meters in diameter) intruded into TIB-1, seem to be limited to the eastern edge of the pegmatite field and Tysford window (Fig. 1).

The U-Pb columbite ages of the Tiltvika and Hundholmen Group 1 metapegmatites hosted by the TIB-1 granites, are $1772.4 \pm 2.9 \mathrm{Ma}$ and $1755.9 \pm 4.9 \mathrm{Ma}$, respectively. Note that these $\mathrm{U}-\mathrm{Pb}$ ages may not be accurate as they were determined on strongly metamict columbite that was annealed before analysis. The sample from Drag shows a similar data distribution as Tiltvika and Hundholmen columbite and, thus, is likely to have a Neoproterozoic formation age, which due to Caledonian recrystallization with associated $\mathrm{Pb}$ loss, cannot be determined precisely. The amphibolite-facies Caledonian metamorphism resulted in the partial resetting of the U-Pb systems of zircon and columbite that now define discordant arrays between an early Proterozoic and an early Paleozoic event. Thus, the accuracy and precision of the data should not be overinterpreted. The formation of the Group 1 metapegmatites is likely to be related to the TIB-1 granite emplacement.

The similarity of bulk chemistries of the most evolved TIB granites and the Jennyhaugen metapegmatite strongly implies a genetic link between the Group 1 metapegmatites and TIB granites (Fig. 5). The upper-crust-normalized pattern of the Jennyhaugen metapegmatite is similar to that of the TIB granites expect for the lower LREE contents (Fig. 9). The low LREE is caused by crystal fractionation of allanite-(Ce), monazite-(Ce) and fluorapatite (these are the major carriers of the LREE in the TIB granites; Müller 2011) in the analysed wall zone of the Jennyhaugen metapegmatite. The lower $\mathrm{Ba}, \mathrm{Ti}, \mathrm{Sr}, \mathrm{Eu}$ and $\mathrm{Zr}$ suggest a higher degree of fractionation of the pegmatites than the TIB granites. The mineralogy of the Group 1 metapegmatites characterises them as NYF pegmatites particularly enriched in fluorite and allanite- $(\mathrm{Ce})$ with a chemical A-type granite signature, similar to the TIB granites. Fluorite and allanite-(Ce) are also common accessories of the Tysfjord granite gneiss (Müller 2011).

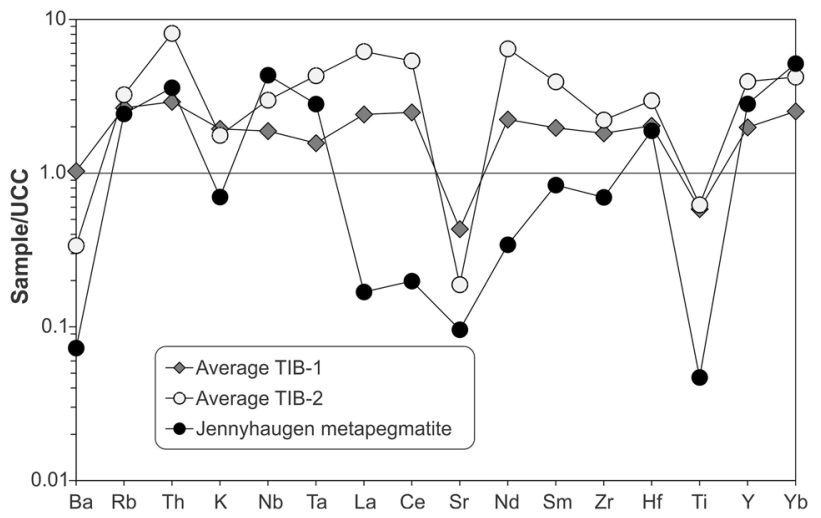

Fig. 9 Diagram of UCC-normalized trace elements of TIB-1 and TIB-2 granite gneisses of the Tysfjord area and the Jennyhaugen Group 1 metapegmatite (wall zone). UCC values are according to Rudnick and Gao (2004)

The chemical similarity of Group 1 metapegmatites and TIB granite gneisses indicates that the pegmatites could represent residual melts of TIB granites. The extraordinary large size of the Tysfjord metapegmatites of up to several hundred of meters is noteworthy, as intra-plutonic NYF pegmatite typically do not exceed the size of about $10 \mathrm{~m}$ as, for example, the pegmatites of Strzegom in Poland (e.g. Janeczek 2007), Erongo in Namibia (Falster et al. 2018), South Platte district in Colorado (e.g. Simmons et al. 1987) and Königshain in Germany (Thomas and Davidson 2016). Exceptions are NYF-type pegmatites related to Proterozoic rapakivi granites in Ukraine (e.g. Lyckberg 2009) and Finland (e.g. Lyckberg 2006), which can be of up to $100 \mathrm{~m}$ in size. The large size of the Ukranian Volodarsk-Volynski chamber pegmatites and Finish Luumäki pegmatite system possibly reflect that the already largely crystallized rapakivi granites behaved as increasingly brittle bodies, facilitating efficient transport of residual melts and the concentration of incompatible elements, such as F, Rb, Ga, Zr, Hf, Th, $\mathrm{U}$, and REE, that had moderate levels in the rapakivi granites (Lyckberg 2009; Michallik et al. 2017). Both the Finish and Ukrainian rapakivi granites share chemical similarities with the Tysfjord and other TIB granites, in particular high $\mathrm{F}, \mathrm{Th}, \mathrm{U}$ and REE contents and overlapping emplacement ages of granites and pegmatites. High F content of the rapakivi granites and Tysfjord granite gneiss may have triggered and enhanced the separation of relatively large volumes of $\mathrm{F}-\mathrm{H}_{2} \mathrm{O}$-enriched melt proportions as suggested by Michallik et al. (2017), which resulted in the crystallization of unusual large granite-melt-derived NYF pegmatites in the Tysfjord area. 


\section{Group 2 pegmatite formation in the context of Caledonian orogenesis (430-390 Ma) of central Scandinavia}

The evolution of the Scandinavian Caledonides was accompanied by two major types and phases of magmatism, an older phase related to the nappe stacking and a younger phase related to uplift of the orogen (e.g. Nordgulen,et al. 1993; Larsen et al. 2002; Steltenpohl et al. 2003; Barnes et al. 2007). Magmatism in the vicinity of the Tysfjord basement window was, however, less pronounced than in other parts of the Scandinavian Caledonides.

Granites of the older phase (c. 430-420 Ma) resulted from local migmatization and melt segregation after nappe stacking. Migmatites within the Narvik Nappe Complex formed after the peak metamorphism at $432 \pm 2 \mathrm{Ma}$ at conditions of $650-800^{\circ} \mathrm{C}$ and $12 \pm 2 \mathrm{kbar}$ (Northrup 1997). The $427 \pm 6$ Ma old Dragvik granite was emplaced across the thrust between the Ofoten and Niingen nappes (Steltenpohl et al. 2003). The originally reported $\mathrm{Rb}-\mathrm{Sr}$ isochron age of $427 \pm 6 \mathrm{Ma}$ (Steltenpohl et al. 2003) was recalculated using the recommended ${ }^{87} \mathrm{Rb}$ decay constant of $1.3972 \pm 0.0045$ $\left(10^{-11} \mathrm{a}^{-1}\right.$; Villa et al. 2015) to $435 \pm 6 \mathrm{Ma}$. This age, however, does not agree with the observation that the granite cuts the nappe boundaries, because the Ofoten and Niingen nappes were not on top of each other at that time (Steltenpohl et al. 2003). Felsic dykes and small plutons in the Ofoten-Troms region of similar chemical signature and setting as the Dragvik granite have a better constrained age. The emplacement of this suite is dated by the $425 \pm 1 \mathrm{Ma}$ age of the Tennes granite that intruded the Balsfjord Group, which overlies the Narvik Nappe Complex (Augland et al. 2014).

The second magmatic phase at c. $400(-370) \mathrm{Ma}$ occurred at a time when the Caledonian orogen and its foreland were affected by major crustal extension (e.g., Eide et al. 2002). Within the Caledonides, this regime is expressed in the form of extensional reactivation of the basal detachment zones and the exhumation of high- and ultrahigh-grade rocks, today exposed as basement windows in western Norway. The extension reactivated also other thrusts and faults, as for example, the N-S striking structures that were active during the formation of the antiformal stacks of basement rocks that formed during the Caledonian continent-continent collision (e.g. Romer et al. 1994; Eide et al. 2002; Wiest et al. 2020). Reactivation of these structures controlled the orientation of the Group 2 pegmatites between 400 and $379 \mathrm{Ma}$ and provided the conduits for melts and/or fluids that facilitated local melting. In the Tysfjord area, temperatures were at least 550 to $650{ }^{\circ} \mathrm{C}$ during extensional shearing at $395 \pm 5 \mathrm{Ma}$ (U-Pb titanite age; Gromet and Andresen 1993) at the basal contact of the Narvik Nappe Complex and the
Tysfjord granite gneiss at Efjord. Gromet and Andresen (1993) interpreted the $395 \mathrm{Ma}$ age to date the formation of the main foliation along the basement-metasediment contact and in the Tysfjord granite gneiss. For a geothermal gradient of $30-40{ }^{\circ} \mathrm{C} / \mathrm{km}$, this temperature of $550-650{ }^{\circ} \mathrm{C}$ corresponds to a pressure of 3.5-6.5 kbar. At these P-T conditions, fluid-present shear-related partial melting of rocks near the regional detachment horizon could generate the pegmatite melts (e.g. Brown and Korhonen 2009).

The chemistry and mineralogy of Group 2 pegmatites and the Tysfjord granite gneisses are broadly similar. Therefore, the pegmatite melts are interpreted as products of local partial melting of the Tysfjord granite gneisses, which is in line with the absence of coeval granites that could serve as source for the pegmatite melts in the central Scandinavian Caledonides. The Tysfjord granite gneisses are poor in B and granite-derived Group 1 metapegmatites rarely have tourmaline (there is a single sample of schorl and luinaite$(\mathrm{OH})$ from a late fracture in the Hundholmen metapegmatite; Kolitsch et al. 2011). Therefore, abundant tourmaline (Fe-rich fluor-schorl; Kolitsch et al. 2011) in Group 2 pegmatites indicates influx of $\mathrm{B}$, possibly from the B-rich metasediments overthrust by the basement nappes. Tourmaline is known from the metasedimentary rocks of the lower nappes, for example, from Slunkajavrre (Fig. 1B; Mindat 2021). The structure of the Strindfjellet Bend provides evidence that the Tysfjord granite gneiss was overthrusted over Caledonian metasediments in the Tennvatn-Slunkavarre-Hellmobotn area and, thus, metasediments occur at depth, below the granite gneiss. Because the pegmatite melts were emplaced along $\mathrm{N}-\mathrm{S}$-trending extensional fractures, metasedimentderived metamorphic B-enriched fluids might have circulated along these fractures. These fluids may have lowered locally the melting temperature of the Tysfjord granite gneiss (e.g. Chorlton and Martin 1978). According to Chorlton and Martin (1978), the addition of B to a water-saturated granitic system lowers the solidus and partial melting point at $1 \mathrm{kbar}$ by $125^{\circ} \mathrm{C}$ to about $600{ }^{\circ} \mathrm{C}$.

Hetherington et al. (2021) reported a combined 410-400 Ma age (U-Pb zircon, allanite-(Ce), fergusonite-(Y), uraninite) for the Stetind pegmatite confirming our Caledonian ages of Group 2 pegmatites. Hetherington et al. (2021) interpret the age as the crystallization age of the pegmatite, which resulted from anatexis of the Tysfjord granite gneiss. We were not able to obtain reliable data for the Stetind pegmatite. Field observations, however, clearly indicate that this pegmatite, which is strongly deformed and recrystallized, belong to the Paleoproterozoic Group 1 of metapegmatites (Fig. 10).

The dated minerals contain several wt $\% \mathrm{U}$ (Table 2 in Hetherington et al. (2021). If they were Paleoproterozoic minerals, they were metamict at the time of the Caledonian orogeny and may have recrystallized during the Caledonian 


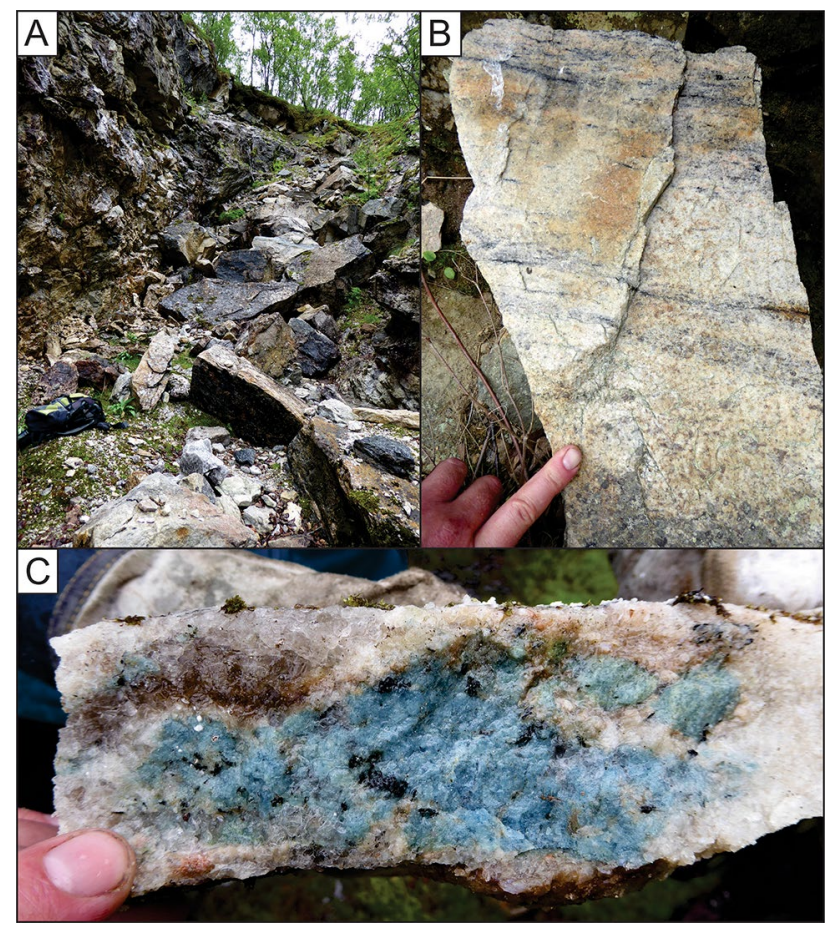

Fig. 10 Field photographs of the Stetind metapegmatite. A Stetind metapegmatite quarry filled with pegmatite blocks. Due to the strong Caledonian foliation, the metapegmatite splits into platy blocks along foliation planes that are coated with recrystallized biotite. B Strongly foliated wall zone of the Stetind metapegmatite. The foliation planes are marked by recrystallized biotite and quartz. C Sheared, fragmented and recrystallized blue beryl in a recrystallized quartz-feldspar matrix

metamorphism excluding $\mathrm{Pb}$ from the recrystallized crystal lattice. Such a reinterpretation of the Hetherington et al. (2021) data agrees with one allanite-(Ce) sample (allanite-2 in Table 2 of Hetherington et al. 2021)that has high ${ }^{206} \mathrm{~Pb} /{ }^{238} \mathrm{U}$ and ${ }^{207} \mathrm{~Pb} /{ }^{235} \mathrm{U}$ ratios of 0.22784 and 1.83201 , respectively, which correspond to older pre-Caledonian apparent ages and provides evidence for inherited radiogenic $\mathrm{Pb}$ from older allanite (cf. Figure 8A). Note, the Stetind allanite falls above the Concordia line to the right of a line through the Caledonian age of $400 \mathrm{Ma}$ of these samples and the origin of the diagram (Fig. 8A), which implies that (1) there was some post $400 \mathrm{Ma} \mathrm{U}$ and $\mathrm{Pb}$ mobility and (2) allanite- 2 contains inherited radiogenic $\mathrm{Pb}$ from a precursor mineral. Therefore, the age provided by Hetherington et al. (2021) represents the age of metamorphism rather than the age of pegmatite formation.

So far, three Group 2 pegmatite localities are known from the northern Tysfjord basement window: Tennvatn, Hellmobotn and Tjeldøya (Fig. 1B). These pegmatites occur in an area of $80 \times 30 \mathrm{~km}$ and, thus, show remelting of the Tysfjord granite gneisses is not a local event. Actually, similar pegmatites involving partial melting of the Svecofennian basement and nappe footwall rocks are also known from other, tectonic windows in the central Scandinavian Caledonides to the southwest of the Tysfjord window. Larsen et al. (2002) described decompression-related migmatization at $398 \pm 2 \mathrm{Ma}$ and pegmatite melt formation at $403 \pm 3 \mathrm{Ma}$ from the Sjona window and the emplacement of pegmatite melts at $409 \pm 5 \mathrm{Ma}$ at the nappe footwall on Træna islands (Fig. 1). These partial melting events are related to top-W to -SW ductile extensional shearing and sinistral strike-slip associated with decompression melting and dome formation during nappe stack unroofing (Larsen et al. 2002). Such a regime is of regional significance (Eide et al. 2002; Braathen et al. 2002; Dewey and Strachan 2003; Osmundsen et al. 2003) and seems to have affected the entire central Scandinavian Caledonides, including the Tysfjord area. Remarkably, the age of the shear-related partial melting decreases from about 410-400 Ma at Træna-Sjona in the southwest to 400-379 Ma at Tysfjord.

\section{Conclusions}

Age data of the granite and (meta-)pegmatite suite exposed in the northern Tysfjord tectonic window reveal that there are two age groups of rare element NYF-type pegmatites that have similar chemical and mineralogical signatures, but different size, structure and deformation degree: the late Svecofennian Group 1 metapegmatites and the late Caledonian Group 2 pegmatites. Group 1 metapegmatites and their hosting granites have similar ages, indicating that the pegmatites formed from residual melts of the hosting granite, which is supported by the similar bulk chemical composition of Group 1 metapegmatites and granites. Group 1 NYFtype metapegmatites form extraordinary large bodies (up to $400 \mathrm{~m}$ ), which may reflect the overall high $\mathrm{F}$ contents of the hosting granites that facilitated the late-stage separation of relatively large volumes of $\mathrm{F}-\mathrm{H}_{2} \mathrm{O}$-enriched melts. Group 1 metapegmatites were metamorphosed and deformed during amphibolite facies Caledonian metamorphism.

Group 2 pegmatites are much smaller. They are undeformed and are interpreted to have formed from fluid-present shear-related partial melting of the Tysfjord granite gneiss during late stages of the Caledonian orogeny between 400 and $379 \mathrm{Ma}$. The high B content of Group 2 pegmatites indicate that external B-rich fluids from Caledonian metasedimentary rocks, which were overthrust by the Tysfjord granite gneiss, may have fluxed melting along reactivated $\mathrm{N}-\mathrm{S}$ striking structures. On the regional scale, partial melting was related to top-W to top-SW ductile extensional shearing of the central Scandinavian Caledonides.

Supplementary Information The online version contains supplementary material available at https://doi.org/10.1007/s00531-022-02166-5. 
Acknowledgements This study is funded by European Commission's Horizon 2020 innovation programme under Grant agreement no. 869274, project GREENPEG New Exploration Tools for European Pegmatite Green-Tech Resources. We highly appreciate the constructive comments of Reinhard Greiling to the manuscript. We would like to thank Astrid Haugen for providing the columbite crystal from the Tennvatn pegmatite used for $\mathrm{U}-\mathrm{Pb}$ dating. We thank Brent Miller and Rune Larsen for careful and constructive reviews and Wolf-Christian Dullo for thoughtful editorial handling.

Funding Open access funding provided by University of Oslo (incl Oslo University Hospital).

Open Access This article is licensed under a Creative Commons Attribution 4.0 International License, which permits use, sharing, adaptation, distribution and reproduction in any medium or format, as long as you give appropriate credit to the original author(s) and the source, provide a link to the Creative Commons licence, and indicate if changes were made. The images or other third party material in this article are included in the article's Creative Commons licence, unless indicated otherwise in a credit line to the material. If material is not included in the article's Creative Commons licence and your intended use is not permitted by statutory regulation or exceeds the permitted use, you will need to obtain permission directly from the copyright holder. To view a copy of this licence, visit http://creativecommons.org/licenses/by/4.0/.

\section{References}

Agyei-Dwarko N, Augland LE, Andresen A (2012) The Heggmovatn supracrustals, North Norway-a late Mesoproterozoic to early Neoproterozoic (1050-930 Ma) terrane of Laurentian origin in the Scandinavian Caledonides. Precambrian Res 212-213:245-262

Åmli R (1975) Råstoffundersøkelse i Nord-Norge. Kvarts- og feltspatundersøkelse i Tysfjord og Hamarøy kommuner. In: Norges Geologiske Unders $\varnothing$ kelse Rapport Nr. 1358/1

Anderson MW, Barker AJ (1999) Caledonian terrane analysis in TromsTornetrask, northern Scandinavia, utilizing the geochemistry of highlevel metabasites. Nor Geol Tidsskr 79:145-159

Andresen A, Steltenpohl M (1994) Evidence for ophiolite obduction, terrane accretion and polyorogenic evolution of the north Scandinavian Caledonides. Tectonophysics 231:59-70

Andresen A, Tull JF (1986) Age and tectonic setting of the Tysfjord gneiss granite, Efjord, North Norway. Nor Geol Tidsskr 66:69-80

Augland LE, Andresen A, Corfu F, Agyei-Dwarko NY, Larionov AN (2013) The Bratten-Landegode gneiss complex: a fragment of Laurentian continental crust in the Uppermost Allochthon of the Scandinavian Caledonides. In: Corfu F, Gasser D, Chew DM (eds) New Perspectives on the Caledonides of Scandinavia and Related Areas, Geological Society, London, Special Publications, vol 390, pp 633-654. https://doi.org/10.1144/SP390.1

Augland LE, Andresen A, Gasser D, Steltenpohl MG (2014) Early Ordovician to Silurian evolution of exotic terranes in the Scandinavian Caledonides of the Ofoten -Troms area - terrane characterization and correlation based on new $\mathrm{U}-\mathrm{Pb}$ zircon ages and $\mathrm{Lu}-\mathrm{Hf}$ isotopic data. In: Corfu F, Gasser D, Chew DM (eds) New Perspectives on the Caledonides of Scandinavia and Related Areas, Geological Society, London, Special Publications, vol 390, pp 655-678. https://doi.org/10.1144/SP390.19
Ballo EG, Augland LE, Hammer $\varnothing$, Svensen HH (2019) A new age model for the Ordovician (Sandbian) K-bentonites in Oslo, Norway. Paleogeogr Paleoclimatol Paleoecol 520:203-213

Barker A (1986) The geology between Salangsdalen and Gratangenfjord, Troms, Norway. Norges Geol Undersokelse Bull 405:41-56

Barnes CG, Frost CD, Yoshinobu AS, McArthur K, Barnes MA, Allen CM, Nordgulen $\varnothing$, Prestvik T (2007) Timing of sedimentation, metamorphism, plutonism in the Helgeland Nappe Complex, north-central Norwegian Caledonides. Geosphere 3(6):683-703

Barros R, Menuge JF (2016) The origin of spodumene pegmatites associated with the Leinster granite in Southeast Ireland. Can Mineral 54:847-862

Bartley JM (1981) Limited basement involvement in Caledonian Deformation, Hinnøy, north Norway, and tectonic implications. Tectonophysics 83:85-203

Bartley JM (1984) Caledonian structural geology and tectonics of east Hinnøy, north Norway. Norges Geol Unders Bull 396:1-124

Baumgartner R, Romer RL, Moritz R, Sallet R, Chiaradia M (2006) Columbite-tantalite pegmatites from the Serid'o Belt, NE Brazil: genetic constraints from $\mathrm{U}-\mathrm{Pb}$ dating and $\mathrm{Pb}$ isotopes. Can Mineral 44:69-86

Bergh S, Kullerud K, Myhre PI, Corfu F, Armitage PEB, Zwaan KB, Ravna EJK (2014) Archaean elements of the basement outliers west of the Scandinavian caledonides in northern Norway: architecture, evolution and possible correlation with fennoscandia. In: Dilek Y, Furnes H (eds) Evolution of archean crust and early life. Springer, Berlin, pp 103-112

Binns RE (1978) Caledonian nappe correlation and orogenic history in Scandinavia north of lat. $67^{\circ} \mathrm{N}$. Geol Soc Am Bull 89:1475-1490

Björklund L (1989) Geology of the Akkajaure-Tysfjord-Lofoten traverse, N. Scandinavian Caledonides. In: PhD thesis, Chalmers Tekniska Högskola och Göteborgs Universitet, Publ. A 59, Gothenburg, Sweden.

Bowring JF, McLean NM, Bowring SA (2011) Engineering cyber infrastructure for $\mathrm{U}-\mathrm{Pb}$ geochronology: Tripoli and $\mathrm{U}-\mathrm{Pb}$ Redux. Geochem Geophys Geosyst 12:Q0AA19. https://doi.org/10.1029/ 2010GC003479

Boyd R (1983) The Lillevik dike complex, Narvik: geoichemistry and tectonic implications of a probable ophiolitic fragment in the Caledonides of the Ofoten region, North Norway. Norsk Geol Tidskrift 63:39-54

Braathen A, Osmundsen PT, Nordgulen $\varnothing$, Roberts D, Meyer GB (2002) Orogen-parallel extension of the Caledonides in northern Central Norway: an overview. Norw J Geol 82:225-241

Brown M, Korhonen FJ (2009) Some remarks on melting and extreme metamorphism of crustal rocks. In: Dasgupta S (ed) Physics and chemistry of the earth. Indian National Science Academy by Springer, New York, pp 67-87

Burt DM (1989) Compositional and phase relations among rare earth element minerals. In: Lipin BR, McKay GA (eds) Geochemistry and mineralogy of rare earth elements. Reviews in mineralogy, vol 21, pp 259-307

Černý P (1989) Characteristics of pegmatite deposits of tantalum. In: Möller P (ed) Lanthanides, tantalum, and niobium. Springer, Berlin, pp 195-239

Černý P (1991) Rare-element granitic pegmatites. II. Regional to global environments and petrogenesis. Geosci Can 18:68-81

Černý P, Ercit TS (2005) Classification of granitic pegmatites revisited. Can Mineral 43:2005-2026

Chorlton LB, Martin RF (1978) The effect on boron on the granite solidus. Can Mineral 16:239-244

Condon DJ, Schoene B, McLean NM, Bowring SA, Parrish RR (2015) Metrology and traceability of U-Pb isotope dilution geochronology (EARTHTIME Tracer Calibration Part I). Geochim Cosmochim Acta 164:464-480 
Corfu F (2004) U-Pb Age, setting and tectonic significance of the anorthosite-mangerite-charnockite-granite suite, LofotenVesterålen, Norway. J Petrol 45:1799-1819

Corfu F, Andersen TB, Gasser D (2014) The Scandinavian Caledonides: main features, conceptual advances and critical questions. In: Corfu F, Gasser D, Chew DM (eds) New perspectives on the Caledonides of Scandinavia and Related Areas, Geological Society, London, Special Publications, vol 390, pp 9-43. https:// doi.org/10.1144/SP390.25

Crowley PD (1985) The structural and metamorphic evolution of the Sitas area, northern Norway and Sweden. In: PhD thesis, Massachusetts Institute of Technology, Cambridge

Dewey JF, Strachan RA (2003) Changing Silurian-Devonian relative plate motion in the Caledonides: sinistral transpression to sinistral transtension. J Geol Soc 160:219-229. https://doi.org/10. 1144/0016-764902-085

Eide EA, Osmundsen PT, Meyer GB, Kendrick MA, Corfu F (2002) The Nesna Shear Zone, north-central Norway: an ${ }^{40} \mathrm{Ar} /{ }^{39} \mathrm{Ar}$ record of Early Devonian-Early Carboniferous ductile extension and unroofing. Norwegian J Geol 82:317-339

Falster AU, Simmons WB, Webber KL, Boudreaux AP (2018) Mineralogy and Geochemistry of the Erongo Sub-Volcanic GraniteMiarolitic-Pegmatite Complex, Erongo, Namibia. Can Mineral 56:425-449

Fei G, Menuge JF, Li Y, Yanga J, Deng Y, Chen C, Yang Y, Yang Z, Qin L, Zheng L, Tang W (2020) Petrogenesis of the Lijiagou spodumene pegmatites in Songpan-Garze Fold Belt, West Sichuan, China: evidence from geochemistry, zircon, cassiterite and coltan $\mathrm{U}-\mathrm{Pb}$ geochronology and $\mathrm{Hf}$ isotopic compositions. Lithos 364-365:105555

Fossen H (2010) Extensional tectonics in the North Atlantic Caledonides: a regional view. In: Law RD, Butler RWH, Holdsworth RE, Krabbedam M, Strachan RA (eds) Continental tectonics and mountain building: the legacy of peach and horne. Geological Society, London, Special Publications, vol 335, pp 767-793

Fuchsloch WC, Nex PAM, Kinnaird JA (2018) Classification, mineralogical and geochemical variations in pegmatites of the Cape Cross-Uis pegmatite belt, Namibia. Lithos 296:79-95

Garate-Olave I, Müller A, Roda-Robles E, Gil-Crespo PP, Pesquera A (2017) Extreme fractionation in a granite-pegmatite system documented by quartz chemistry: The case study of Tres Arroyos (Central Iberian Zone, Spain). Lithos 286-287:162-174. https:// doi.org/10.1016/j.lithos.2017.06.009

Gee DG, Sturt BA (1985) The Caledonide Orogen-Scandinavia and related areas. Wiley, New York

Gee DG, Fossen H, Henriksen N, Higgins AK (2008) From the early paleozoic platforms of Baltica and Laurentia to the Caledonide Orogen of Scandinavia and Greenland. Epsiodes 31:44-51

Gee DG, Stephens MB (2020) Lower thrust sheets in the Caledonide orogen, Sweden: Cryogenian-Silurian sedimentary successions and underlying, imbricated, crystalline basement. In: Stephens MB, Bergman Weihed J (eds) Sweden: Lithotectonic framework, tectonic evolution and mineral resources, Geological Society, London, Memoirs, vol 50, pp 495-515. https://doi.org/10.1144/ M50-2018-7

Gorbatschev R (1985) Precambrian basement of the Caledonides. In: Gee DG, Sturt BA (eds) The Caledonide Orogen-Scandinavia and related areas. Wiley, Chichester, pp 197-212

Greiling RO, Gayer RA, Stephens MB (1993) A basement culmination in the Scandinavina Caledonides form ed by antiformal stacking (Bångonåive, northern Sweden). Geol Mag 130:471-482

Griffin WL, Taylor PN, Hakkinen JW, Heier KS, Iden IK, Krogh EJ, Malm O, Olesen KI, Ormaasen DE, Tveten E (1978) Archean and Proterozoic evolution of Lofoten-Vesterålen, N Norway. J Geol Soc Lond 135:629-647
Grimmer JC, Glodny J, Drüppel K, Greiling RO, Kontny A (2015) Early- to mid-Silurian extrusion wedge tectonics in the central Scandinavian Caledonides. Geology 43:347-350. https://doi.org/ 10.1130/G36433.1

Gromet LP, Andresen A (1993) U-Pb age constrains on Caledonian shear strain developed at the basement-allochthon contact, Ofoten region, Norway. EOS, Transaction American Geophysical Union 74/16, Spring Meeting Suppl, p 123

Hetherington CJ, Mailloux GA, Miller BV (2021) A multi-mineral $\mathrm{U}-(\mathrm{Th})-\mathrm{Pb}$ dating study of the Stetind pegmatite of the Tysfjord region, Norway, and implications for production of NYFrare element pegmatites during orogenic collapse. Lithos 398-399:106257

Hodges KV (1985) Tectonic stratigraphy, and structural evolution of the Efjord-Sitasjaure area, North Scandinavian Caledonides. Norges Geol Unders Bull 399:41-62

Hodges KV, Royden L (1984) Geologic thermobarometry of retrograded metamorphic rocks - an indication of the uplift trajectory of a portion of the northern Scandinavian Caledonides. J Geophys Res 89:7077-7090

Hodges KV, Bartley JM, Burchfiel BC (1982) Structural evolution of an A-type subduction zone, Lofoten-Rombak area, northern Scandinavian Caledonides. Tectonics 1:441-462

Hodges KV (1982) Tectonic evolution of the Aefjord-Sitas area, Norway-Sweden. In: PhD thesis, Massachusetts Institute of Technology, Cambridge

Högdahl K, Andersson UB, Eklund O (2004) The Transscandinavian Igneous Belt (TIB) in Sweden: a review of its character and evolution. In: Geological Survey of Finland, Special Paper, vol 37, p 125

Husdal T (2008) The minerals of the pegmatites within the Tysfjord granite, northern Norway. Norsk Bergverksmuseum Skrift 38:5-28

Huyskens MH, Zink S, Amelin Y (2016) Evaluation of temperaturetime conditions for the chemical abrasion treatment of single zircons for U-Pb geochronology. Chem Geol 438:25-35

Ilickovic T, Schuster R, Mali H, Onuk P, Horschinegg M (2017) Genesis of spodumene pegmatites in the Austroalpine unit (Eastern Alps): isotopic and geochemical investigations. In: 8th international symposium on granitic Pegmatites, Kristiansand, Norway, NGF Abstracts and Proceedings, vol 2, pp 54-57

Jaffey AH, Flynn KF, Glendenin LE, Bentley WC, Essling AM (1971) Precision measurements of half-lives and specific activities of ${ }^{235} \mathrm{U}$ and ${ }^{238} \mathrm{U}$. Phys Rev C 4:1889-1906

Janeczek J (2007) Intragranitic pegmatites of the Strzegom-Sobotka massif-an overview. Granitoids Poland AM Monogr No 1:193-201

Karlsen TA (2000) Economic potential of potassic feldspar-rich gneisses in Tysfjord/Hamarøy, northern Norway. Norges Geol Unders Bull 436:129-135

Kirkland CL, Daly JS, Chew DM, Page LM (2008) The Finnmarkian Orogeny revisited: an isotopic investigation in eastern Finnmark, Arctic Norway. Tectonophysics 460:158-177

Knoll T, Schuster R, Huet B (2018) Spodumene pegmatites and related leucogranites from the Austroalpine Unit (Eastern Alps, Central Europe): field relations, petrography, geochemistry and geochronology. Can Mineral 56:489-528

Kolitsch U, Husdal TA, Brandstätter F, Ertl A (2011) New crystalchemical data for members of the tourmaline group from Norway: occurrences of fluor-schorl and luinaite- $(\mathrm{OH})$. Norsk Bergverksmuseum Skrift 46:17-24

Konzett J, Schneider T, Nedyalkova L, Hauzenberger C, Melcher F, Gerdes A, Whitehouse M (2018) Anatectic granitic pegmatites from the Eastern Alps: a case of variable rare-metal enrichment during high-grade regional metamorphism-I: mineral 
assemblages, geochemical characteristics, and emplacement ages. Can Mineral 56:555-602

Kroner U, Stephan T, Romer RL, Roscher M (2020) Paleozoic plate kinematics during the Pannotia-Pangaea supercontinent cycle. Geol Soc Lond Spec Publ 503:83-104

Lahtinen R, Garde AA, Melezhik VA (2008) Paleoproterozoic evolution of Fennoscandia and Greenland. Episodes 31:20-28

Lahtinen R, Korja A, Nironen M, Heikkinen P (2009) Palaeoproterozoic accretionary processes in Fennoscandia. In: Cawood PA, Kröner A (eds) Earth accretionary systems in space and time. The Geological Society, London, Special Publications, vol 318, pp 237-256

Larsen Ø, Skår Ø, Pedersen R-B (2002) U-Pb zircon and titanite geochronological constraints on the late/post-Caledonian evolution of the Scandinavian Caledonides in north-central Norway. Nor Geol Tidsskr 82:1-13

Lindroos A, Romer RL, Ehlers C, Alviola R (1996) Late-orogenic Svecofennian deformation in SW Finland constrained through pegmatite emplacement ages. Terra Nova 8:567-574

Lindstrøm M (1988) Rb-Sr geokronologi av prekambriske og kaledonske bergarter i Ofoten og Troms. PhD thesis, University of Troms $\varnothing$, Norway

London D (2008) Pegmatites. Can Mineral Spec Publ 2008:10

Ludwig KR (2003) User's manual for ISOPLOT 3.00: a geochronological toolkit for Microsoft Excel. Berkeley Geochronol Center Spec Publ 4:4

Lyckberg P (2006) Miarolitic pegmatites of the Viborg rapakivi granite massif, SE Finland with special attention to the green gem beryl producing Karelia Beryl Mine pegmatite at Luumäki, Karelia. Norsk Bergverksmuseum Skrift 33:87-107

Lyckberg P (2009) Volodarsk-Volynski Chamber Pegmatites. Mineral Rec 40:473-506

Mattinson JM (2005) Zircon U-Pb chemical abrasion ("CA-TIMS”) method: combined annealing and multi-step partial dissolution analysis for improved precision and accuracy of zircon ages. Chem Geol 220:47-66

Melcher F, Graupner T, Gäbler H-E, Sitnikova M, Oberthür T, Gerdes A, Badanina E, Chudy T (2016) Mineralogical and chemical evolution of tantalum-(niobium-tin) mineralisation in pegmatites and granites. Part 2: Worldwide examples (excluding Africa) and an overview of global metallogenetic patterns. Ore Geol Rev 89:946-987. https://doi.org/10.1016/j.oregeorev.2016.03.014

Melezhik VA, Roberts D, Gorokhov IM, Fallick AE, Zwaan KB, Kuznetsov AB, Pokrovsky BG (2002) Isotopic evidence for a complex Neoproterozoic to Silurian rock assemblage in the north-central Norwegian Caledonides. Precambr Res 114:55-86

Michallik RM, Wagner T, Fusswinkel T, Heinonen JS, Heikkilä P (2017) Chemical evolution and origin of the Luumäki gem beryl pegmatite: Constraints from mineral trace element chemistry and fractionation modeling. Lithos 274-275:147-168

Mindat (2021) Slunkajavrre, Hamarøy, Nordland, Norway. https:// www.mindat.org/loc-247989.html. Accessed 15 Jul 2021

Müller A (2011) Potential of rare earth element and Zr-, Be-, U-, Th-, (W-) mineralisations in central and northern Nordland-Part 2. Norges Geol Undersøkelse Rapport 2011:021

Müller A, Ihlen PM, Snook B, Larsen RB, Flem B, Bingen B, Williamson BJ (2015) The Chemistry of quartz in granitic pegmatites of southern Norway: Petrogenetic and economic implications. Econ Geol 110:1737-1757. https://doi.org/10.2113/econgeo. 110.7.1737

Müller A, Romer RL, Pedersen RB (2017) The Sveconorwegian pegmatite province - thousands of pegmatites without parental granites. Can Mineral 55:283-315

Müller A, Simmons W, Beurlen H, Thomas R, Ihlen PM, Wise M, Roda-Robles E, Neiva AMR, Zagorsky V (2021) A proposed new mineralogical classification system for granitic pegmatites-Part
I: history and the need for a new classification. Can Mineral. https://doi.org/10.3749/canmin.1700088

Müller A, Snook B, Ihlen MP, Beurlen H, Breiter K (2013) Diversity of the quartz chemistry of NYF- and LCT-type pegmatites and its economic implications. Mineral deposit research for a high-tech world. In: Proceedings of the 12th Biennial SGA Meeting, Vol. 4, 12-15 August 2013, Uppsala, Sweden, ISBN 978-91-7403207-9, pp 1774-1776

Nordgulen $\varnothing$, Bickford ME, Nissen AL, Wortman GL (1993) U-Pb zircon ages from the Bindal Batholith, and the tectonic history of the Helgeland Nappe Complex, Scandinavian Caledonides. J Geol Soc 150(4):771-783

Northrup CJ (1997) Timing structural assembly, metamorphism, and cooling of the Caledonian nappes in the Ofoten-Efjorden area, north Norway: tectonic insights from U-Pb and ${ }^{40} \mathrm{Ar} /{ }^{39} \mathrm{Ar}$ geochronology. J Geol 105:565-582

Osmundsen PT, Braathen A, Nordgulen Ø, Roberts D, Meyer GB, Eide E (2003) The Devonian Nesna shear zone and adjacent gneisscored culminations, North-Central Norwegian Caledonides. J Geol Soc Lond 60:1-14

Rice AHN (2001) Field evidence for thrusting of the basement rocks coring tectonic windows in the Scandinavian Caledonides; an insight from the Kunes Nappe, Finnmark, Norway. Nor Geol Tidsskr 81:321-328

Rice AHN, Anderson MW (2016) Restoration of the external Scandinavian Caledonides. Geol Mag 153:1136-1165. https://doi.org/ $10.1017 /$ S0016756816000340

Roberts D, Nordgulen Ø, Melezhik V (2007) The Uppermost Allochthon in the Scandinavian Caledonides: From a Laurentian ancestry through Taconian orogeny to Scandian crustal growth on Baltica. In: Hatcher RD Jr et al (eds) 4-D framework of continental crust, Geological Society of America Memoir, vol 200, pp 357-377. https://doi.org/10.1130/2007.1200(18)

Roberts D, Gee DG (1985) An introduction to the structure of the Scandinavian Caledonides. In: Gee DG, Sturt BA (eds) The Caledonide Orogen - Scandinavia and related areas. Wiley, New York, pp 55-68

Roda-Robles E, Villaseca C, Pesquera A, Gil-Crespo PP, Vieira R, Lima A, Garate-Olave I (2018) Petrogenetic relationships between Variscan granitoids and Li-(F-P)-rich aplite-pegmatites in the Central Iberian Zone: Geological and geochemical constraints and implications for other regions from the European Variscides. Ore Geol Rev 95:408-430

Romer RL (1997) U-Pb age of rare-mineral pegmatites at Stora Vika. Geol Fören Stockh Förh 119:291-294

Romer RL (2003) Alpha-recoil in U-Pb geochronology: effective sample size matters. Contr Mineral Petrol 145:481-491

Romer RL, Bax G (1992) The rhombohedral framework of the Scandinavian Caledonides and their foreland. Geol Rundschau 81(2):391-401

Romer RL, Smeds S-A (1994) Implications of U-Pb ages of columbite-tantalites from granitic pegmatites for the Palaeoproterozoic accrection of 1.90-1.85 Ga magmatic arcs to the Baltic Shield. Precambrian Res 67:141-158

Romer RL, Smeds S-A (1996) U-Pb columbite ages of pegmatites from Sveconorwegian terranes in southwestern Sweden. Precambrian Res 76:15-30

Romer RL, Smeds S-A (1997) U-Pb columbite chronology of postkinematic Palaeoproterozoic pegmatites in Sweden. Precambrian Res 82:85-99

Romer RL, Wright JE (1992) U-Pb dating of columbites: a geochronologic tool to date magmatism, metamorphism, and ore deposits. Geochim Cosmochim Acta 56:2137-2142

Romer RL, Kjøsnes B, Korneliussen A, Lindahl I, Skyseth T, Stendal M, Sundvoll B (1992) The Archaean-Proterozoic boundary beneath the Caledonides of northern Norway and Sweden: 
$\mathrm{U}-\mathrm{Pb}, \mathrm{Rb}-\mathrm{Sr}$ and $\mathrm{Nd}$ isotope data from the Rombak-Tysfjord area. Norges Geol Undersøkelse Report 91:225

Romer RL, Bax G, Kathol B (1994) Basement control of the Caledonian orogen along the Torneträsk section, northern Sweden. Schweiz Mineral Petrogr Mitt 74:469-481

Romer RL, Nowaczyk N, Wirth R (2007) Secondary Fe-Mn-oxides in minerals heavily damaged by a-recoil: possible implications for palaeomagnetism. Int J Earth Sci 96:375-387

Rudnick RL, Gao S (2004) Composition of the continental crust. In: Holland HD, Turekian KK (eds) Treatise on geochemistry, vol 3. Elsevier, Amsterdam, pp 1-64

Schmitz MD, Schoene B (2007) Derivation of isotope ratios, errors and error correlations for $\mathrm{U}-\mathrm{Pb}$ geochronology using ${ }^{205} \mathrm{~Pb}-$ ${ }^{235} \mathrm{U}-\left({ }^{233} \mathrm{U}\right)$-spiked isotope dilution thermal ionization mass spectrometric data. Geochem Geophys Geosyst 8:Q08006

Schuster R, Ilickovic T, Mali H, Huet B, Schedl A (2017) Permian pegmatites and spodumene pegmatites in the Alps: Formation during regional scale high temperature/low pressure metamorphism. In: Müller A, Rosing-Schow N (eds) 8th international symposium on granitic pegmatites. NGF abstracts and proceedings, Kristiansand, Norway, pp 122-125

Simmons WB, Lee MT, Brewster RH (1987) Geochemistry and evolution of the South Platte granite-pegmatite system, Jefferson County, Colorado. Geochim Cosmochim Acta 51:455-471

Simmons WB, Falster A, Webber K, Roda-Robles E, Boudreaux AP, Grassi LR, Freeman G (2016) Bulk composition of Mt. Mica pegmatite, Maine, USA: implications for the origin of an LCT type pegmatite by anatexis. Can Mineral 54:1053-1070

Simmons WB, Foord EE, Falster AU (1996) Anatectic origin of granitic pegmatites, Western Maine, USA, GAC-MAC Annual meeting-Abstracts with Programs, University of Manitoba, Winnipeg, USA

Skår Ø (2002) U-Pb geochronology and geochemistry of early Proterozoic rocks of the tectonic basement windows in central Nordland, Caledonides of northcentral Norway. Precambrian Res 116:265-283

Stacey JS, Kramers JD (1975) Approximation of terrestrial lead isotope evolution by a two-stage model. Earth Planet Sci Lett 26:207-221

Steltenpohl MG, Andresen A, Tull JF (1990) Lithostratigraphic correlation of the Salangen (Ofoten) and Balsfjord (Troms) Groups: evidence for the postFinnmarkian unconformity, north Norwegian Caledonides. Nor Geol Unders 418:61-77

Steltenpohl MG, Andresen A, Lindstrøm M, Gromet P, Steltenpohl LW (2003) The role of felsic and mafic igneous rocks in deciphering the evolution of thrust-stacked terranes: an example from the north Norwegian Caledonides. Am J Sci 303:149-185

Steltenpohl MG, Andresen A (1991) Nappe sequences in the Ofoten region: Implications for terrane accretion, ophiolite obduction, and polyorogenic evolution. In: Andresen A, Steltenpohl MG (eds) A geotraverse excursion through the Scandinavian Caledonides: Tornetrask-Ofoten-Tromso: International Geologic Correlation Project, vol 233, pp 4.1-4.19

Steltenpohl MG, Bartley JM (1987) Thermobarometric profile through the Caledonian nappe stack of western Ofoten, north Norway: Contrib Mineral Petrol, vol 96, pp 93-103

Stephens MB (1988) The Scandinavian Caledonides: a complexity of collisions. Geol Today 4:20-26

Suominen V (1991) The chronostratigraphy of SW Finland with special reference to the Postjotnian and Subjotnian diabases. Geol Surv Finland Bull 1991:356

Thelander T, Bakker E, Nicholson R (1980) Basement-cover relationships in the Nasafjäll Window, central Swedish Caledonides. Geol Fören Stockh Förh 102:569-580

Thomas R, Davidson P (2016) Origin of miarolitic pegmatites in the Königshain granite/Lusatia. Lithos 260:225-241

Tull JF, Bartley JM, Hodges KV, Andresen A, Steltenpohl MG, White JM (1985) The Caledonides in the Ofoten region $\left(68^{\circ}-69^{\circ} \mathrm{N}\right)$, north Norway: key aspects of tectonic evolution. In: Gee DG, Sturt BA (eds) The Caledonide Orogen-Scandinavia and Related Areas. Wiley, Chichester, pp 553-568

Turekian KK, Wedepohl KH (1961) Distribution of the elements in some major unites of the Earth's crust. Bull Geol Soc Am 72:172-202

Vaasjoki M, Rämö OT, Sakko M (1991) New U-Pb ages from the Wiborg rapakivi area: constraints on the temporal evolution of the rapakivi granite-anorthosite-diabase dike association of southeastern Finland. In: Haapala I, Condie KC (eds) Precambrian granitoids-petrogenesis, geochemistry and metallogeny. Precambrian res, vol 51, pp 227-243

Villa IM, De Bievre P, Holden NE, Renne PR (2015) IUPAC-IUGS recommendation on the half-life of ${ }^{87} \mathrm{Rb}$. Geochim Cosmochim Acta 164:382-385

Webber K, Simmons WB, Falster AU, Hanson SL (2019) Anatectic pegmatites of the Oxford County pegmatite field, Maine, USA. In: Wise M, Brown C, Simmons WB, Roda-Robles E, Webber K (eds) 9th international symposium on granitic pegmatites, Pala, California, USA, pp 87-90

Wiest JD, Jacobs J, Fossen H, Ganerød M, Osmundsen PT (2020) Segmentation of the Caledonian orogenic infrastructure and exhumation of the Western Gneiss Region during transtensional collapse. J Geol Soc Lond 178:199. https://doi.org/10.1144/jgs2020-199

Yoshinobu AS, Barnes CG, Nordgulen $\emptyset$, Prestvik T, Fanning M, Pedersen RB (2002) Ordovician magmatism, deformation, and exhumation in the Caledonides of central Norway: an orphan of the Taconic orogeny? Geology 30(10):883-886 